\title{
FEDERAL REGULATION OF MOTOR CARRIER UNIFICATION
}

JOHN F. MECK, JR.†

ROBERT W. BOGUE††

THE motor carrier industry of today has progressed far from its meager beginnings during World War I. Successfully resisting railroad efforts to stunt its growth, it has assumed within the past decade a position of substantial importance and has been largely responsible for returning transportation as a whole to a competitive pattern. Throughout its development motor carriage has displayed two distinctive characteristics. Intense competition between numerous small operators has gone hand in hand with and partly contributed to the steady process of unification of small carriers into somewhat larger units. More recently, and notwithstanding the Motor Carrier Act of 1935 with its requirement that combination transactions be "consistent with the public interest," this unification trend has been proceeding at a constantly accelerated pace.

Large scale unification, however, with its need for large capital, has been another matter. Investors have been slow to abandon their fear of the turbulent uncertainties flowing from the severe competition in motor carriage. The bus industry was more responsive than the truck industry to the inducements of a large scale operation. ${ }^{2}$ Even before 1935 Greyhound had emerged as an important exception to the general predominance of small-operators. Indeed, it was not until after the enactment of the Motor Carrier Act of 1935 that carriage of freight by motor truck appeared sufficiently stable to justify expansion and to interest the capital market in financing that expansion. Lehman Brothers led the way in 1937 by lending financial support to substantial

† Assistant Dean, Yale Law School.

t Sterling Fellow, Yale Law School; Member, District of Columbia Bar.

1. 49 StAT. 543, 555 (1935), 49 U. S. C. $\$ 313($ a) (1) (Supp. 1939) (hercinafter cited as Motor CArrier Act).

2. 54th ANn. Rep. I. C. C. (1940) 32. The legislative history of federal motor carrier regulation neatly illustrates the point. Early bills proposed regulation for both busses and trucks. S. 1734, 69th Cong., 1st Sess. (1925), and H. R. 8266, 69th Cong., 1st Sess. (1926). Subsequently, yielding to contentions made by trucking interests that the large number of truck operators and their small size make efficient regulation impossible, bills were introduced which limited regulation to the more completely organized bus industry. S. 1252, 70th Cong., 1st Sess. (1927) ; H. R. 12380 and S. 3992, 70th Cong., 1st Sess. (1928). Subsequently, other bills restricting regulation to busses were introduced into Congress, and one of them, H. R. 10288, 71st Cong., 2d Sess. (1930), was passed by the House. See Note 18 infra. See also Johnson, Government Regulation of TransPORTATION (1938) 572. 
acquisitions by Keeshin Transcontinental Freight Lines, ${ }^{3}$ but the unimpressive record of this first experiment served to emplasize the risks involved rather than to encourage large scale operation." Then in 1940, with Kuhn-Loeb backing, came a second departure from financier hesitation and a decision to assume the risks in a venture far greater than that carried out in the Keeshin unification - the formation of the Transport Company of New York. To picture the Transport Company is to visualize a powerful unified corporation, combining 49 motor carrier companies which owned 10,600 units of equipment and employed 9,700 persons, engaged in operating motor trucks over a web of routes spun systematically upon the eastern seaboard from the Piedmont region of the Carolinas into the heart of New England." Conceived in terms of profits and contemplating a public offering of securities, the Transport Company was viewed with keen interest by the financial community and the decision of the Interstate Commerce Commission as to whether the transaction was "consistent with the public interest" was eagerly awaited. Interest changed to enthusiasm and even exuberance after a generally favorable report was proposed to the Commission by its Bureau of Finance Examiner. ${ }^{6}$ Rumors of new integrations sprang up the country over, and at long last the motor carrier industry seemed about to enter "big-time."

The Interstate Commerce Commission, however, thought otherwise. Acknowledging that its decision would fix the pattern for future unification activity, it upset the generally favorable report with a positive denial of authority on November 15, 1940..$^{7}$ Unfortunately, neither the majority opinion nor Commissioner Eastman's special concurrence, nor both together, present a very lucid exposition of the Commission's attitude toward large scale combination, for the opinions were written

3. Keeshin Transcon. Frt. Lines, Inc.-Control, 1 M. C. C. 317 (1936); Keeshin Motor Exp. Co., Inc. (Illinois)-Leases, 1 M. C. C. 373 (1936); Keeshin Transcon. Frt. Lines, Inc-Control, 5 Mr. C. C. 25 (1937); Freight by Hightcay (Feb. 1936) 13 Fortune 47.

4. Keeshin Freight Lines, Inc-Issuance of Notes, 35 M. C. C. 119 (1940).

5. The Transport Co.-Control, 36 M. C. C. 61 (1940). Of the 49 companies, 39 were over-the-road companies (12 being subsidiaries of the other companies), and 10 were rental companies.

6. The Transport Co.-Control, Proposed Report by J. Edward Davey, Chief, Section of Finance, Bureau of Motor Carriers, Oct. 11, 1940 (mimeographed).

7. The Transport Co.-Control, 36 M. C. C. 61 (1940). One of the most peculiar aspects of the Transport case was the conspicuous absence of railread opposition. No certain guess at railroad motivation is possible, but this statement appeared in an editorial in the motor truck trade journal: "It has been rumored the railroads are pulling for the combine because it would place a major part of their competition under one management. Competitive practices could then be watched far more easily than is now possible. And their theory is that the bankers have called off railroad opposition." Transport Topics, July 22, 1940, Vol. 14, No. 43, p. 4. 
in terms of the narrow rather than the broad issues. Four principal reasons were set forth for holding the Transport Company's application not consistent 'with the public interest: (1) unconvincing evidence of resulting economies, (2) possible undesirable elimination of motor carrier competition, (3) failure to simplify corporate structure, and (4) excessive consideration to vendors and immoderate fees to promoters.

While an over-all consideration of these four reasons seems necessary to explain the result reached in the Transport case, an independent evaluation of each is essential in any attempt to grasp the Commission's policy toward large scale unification. The possibility of effecting economies and improving service by integrated operation was carefully appraised in the Examiner's report and found persuasive. The Commission, however, was unimpressed and apparently even uninterested, for the case for economies was set forth but neither analyzed nor criticized and served no purpose other than to provide an unnecessary preface to this cavalier conclusion:

"In the absence of evidence that similar consolidations or expansions of operations on such a large scale have produced results anticipated by applicant, the testimony with respect to proposed economies and improvements in service is not convincing." 8

Strictly interpreted and carefully observed, this dogmatism would bar unifications upon a scale more extensive than those now being successfully operated. Skepticism of optimistic estimates of economies is understandable, especially since expansions by Keeshin Transcontinental Freight Lines had portended similar savings which failed to materialize. ${ }^{0}$ But to substitute for articulate analysis a rule of thumb which, if consistently applied, would freeze motor carrier operation at its present level is hardly understandable.

The Examiner's report, after an effort to uncover any undesirable elimination of motor carrier competition, found that numerous and strong competing carriers would continue to render service throughout the regions to be served by the Transport Company. ${ }^{10}$ The Commission again found to the contrary. Although it conceded that substantial motor carrier competition would remain in most of the New England and Middle Atlantic sections, it was "left in doubt" as to whether such competition would exist on traffic moving between southern points and points

8. The Transport Co.-Control, 36 M. C. C. 61,78 . (Italics supplied).

9. Keeshin Frt. Lines, Inc.-Issuance of Notes, 35 M. C. C. 119 (1940).

10. See Davey, note 6 supra at 61-69. The motor carriers which would provide the Transport Company with competition were analyzed according to area served, and it was found that there would continue to be competition from 168 carriers, 56 of them Class I, in New England, 182 carriers, not segregated according to classes, in New York State, "several hundred" carriers between New York and Washington, and 90 carriers, 24 of them Class I, in the Southern region. 
north of Baltimore. Commissioner Eastman demurred to this reservation, and suggested that attention should be shifted from motor carrier competition remaining within the area to other factors operating to prevent monopoly such as competition from railroads and private truckers, and issuance of new certificates of public convenience and necessity.

The Transport Company, anticipating Commission disapproval of its complex corporate structure with many subsidiaries rendering duplicate services within the same areas, filed supplemental applications proposing to effect singleness of title in Transport itself. But no specific plan for this simplification was presented, and the Commission refused to issue carte blanche authority for later merger or consolidation. Expressing doubt as to its own power to compel later adoption of a desirable plan to accomplish this object, the Commission chose to treat the case as if no singleness of title had been promised, and accordingly found the maintenance of multiple corporations engaged in substantially duplicate operations uneconomical and contrary to the public interest. ${ }^{11}$

The strongest objections of the Commission, however, were apparently leveled at the two defects of finance: excessive consideration for the carrier properties to be acquired and exorbitant fees for promotion, with neither the vendors nor the promoters retaining any considerable stalie in the enterprise. The total consideration of over $\$ 22,500,000$, largely cash, was 2.12 times the value of the tangible assets to be acquired, 8.81 times the adjusted net income of the vendors in 1939 , and 24.62 times their average net income for the three years 1937-1939. ${ }^{12}$ Yet in the industry a ratio of 6 times net earnings is ordinarily considered indicative of sound value in acquisitions. ${ }^{13}$ The unification transaction also contemplated the payment of cash commissions approximating $\$ 1,225,000$ to the underwriters for negotiating the public sale of Transport Company's preferred and common stock, and the issuance of additional common stock valued at $\$ 2,200,000$ to the promoters for their services, presumably to be eventually sold to the public. ${ }^{14}$ Organization

11. The Transport Co.-Control, 36 Mr. C. C. $61,86$.

12. Id. at 90 .

13. In his concurring opinion Commissioner Eastman said at 97: "There is much evidence, quite comprehensive in character, leading to the conclusion that prospective earning power will justify such a price. Yet the motor carrier industry is still in its early youth, there is no background of experience by which the probable results of such a unification as is proposed can be gauged, and transportation competition is now so intense as to multiply the hazards of the future."

14. Id. at 90, 92. It was proposed that Transport Company should issue 100,090 shares of restricted common stock, par value of \$1 a share, to Kuhn-Loeb \& Company. By issuing the stock with $\$ 1$ par value it was possible to avoid the necessity of Commission approval since the total par value was less than $\$ 500,000$. MIoron Camnes Act \$214. Yet the plan for the further issue of common stock subject to Commission approval contemplated that it should have an actual value of at least $\$ 20$ a share and that it should be issued at that price notwithstanding its par value of $\$ 1$ a share. The stock issued to 
expenditures were found to amount to only $\$ 200,000$; yet the total cost of financing was to exceed $\$ 3,000,000$, or $14 \%$ of the total value of Transport Company's capital stock. While the Examiner's report proposed merely to reduce the promoters' commissions to $10 \%$ of the capital stock value, leaving underwriting commissions the same, no such half way measure was satisfactory to the Commission which stated flatly:

"We believe that unifications of motor carriers are more likely to be on a sound basis, and the prospects of ultimate success improved, if they be brought about through the initiative, and negotiations between the carriers involved, or between persons financially interested in such carriers who retain a substantial interest in the enterprise, without the use of holding company devices or the intervention of promoters, particularly where such intervention would substantially increase ultimate costs." 15

The Transport case is undoubtedly the most important decision involving motor carrier unification rendered by the Commission under the Motor Carrier Act of 1935. In one form or another it involves virtually every problem with which the Commission has struggled. In addition, it dramatically presents the controversy over large as against small scale operation. ${ }^{16}$ But a resolution of this conflict was certainly not reached in this case. The broad question of the proper position of the large company in the motor carrier field went unmentioned, and questions of economy in large scale operation and permissible consideration for intangible assets were unsatisfactorily handled. The result and some of the language used, if accepted literally, would almost destroy the prospect of large scale combination. Yet there are reasons to believe that the Transport case does not represent a drastic departure from the underlying policy of the Motor Carrier Act to foster controlled inte-

Kuhn-Loeb would then likewise acquire a value of $\$ 20$ or more per share and presumably be marketable at that price or better. Commissioner Eastman reviewed the scheme, and then stated at 99: "This arrangement is a shrewd device for insuring the desired compensation for promoters and bankers without bringing it under our supervision. We should not approve such a plan."

15. The Transport Co.-Control, 36 M. C. C. 61, 92.

16. "An important reason for the success which motortrucks have often had in competing with the railroads for various types of traffic has been the great flexibility of motortruck service and its ability to adjust itself readily to the special needs of the shipper. There are those who feel that when motortruck operations conducted under a single management increase beyond a certain size there is a tendency to sacrifice this advantage of flexibility, because of the fact that contact with the shipper must more and more be maintained through subordinates acting under instructions. It is possible that for this and other reasons there is a limit to increase in efficiency with increase in size of motortruck operations and that beyond this limit efficiency tends to decrease. However, only actual experience can determine this, and from that point of view the test of large-scale operations which applicant is making is desirable." Keeshin Transcon. Frt. Liıes, Inc.Control, 5 M. C. C. 25, 35 (1937). See also Nelson, Economics of Large Scale Operation in the Trucking Industry (1941) 17 J. of LAND \& PUB. Util. ECoN. 112. 
gration and restrict ruthless competition on the theory that economies and improved service result from large scale operation. The financial aspects of the transaction bore many of the earmarks of an anachronistic promotion belonging more properly in an earlier era of American finance. Particularly relevant was Commissioner Eastman's caveat suggesting that if the vendors and promoters had been willing to accept and hold stock instead of cash, thereby taking "pot-luck" with the public in sharing the risks of the enterprise, the transaction might have been approved. In other words, it is possible that the Commission primarily sought to preclude the establishment of a tradition of lusty finance in motor carriage, and the balance of the opinion was mainly "window dressing." This hypothesis will soon be tested in some measure, since seven of the over-the-road companies involved in the Transport case, together with seven of their subsidiaries, have applied for authority to combine into a single concern, which, in terms of total consideration and net income, will be almost half the size of the Transport Company and will afford truck service from New England to Florida. ${ }^{17}$ The financial arrangements of this new unification were specifically drawn to meet the Commission's objections in the Transport case. All the negotiations were conducted by the truck operators themselves, who as vendors plan to take stock in the new company in return for their properties. No public financing is to be undertaken except a small offering of preferred stock to obtain working capital, and promotional fees are to be wholly eliminated. Thus, it seems very certain that in the near future the Commission will be compelled to state more clearly its views on largescale unification. In any event the time seems ripe for an appraisal of motor carrier unification and a general examination of Commission activity in the field prior to and since the Transport case.

\section{Legislative History of Regulated Unification}

Federal regulation of motor carriers in general, and without specific reference to unification, was first demanded early in the 'twenties as

17. The transaction takes the form of an acquisition of control of the stocts of the seven companies by a parent company, Associated Transport, Inc. The seven companies involved are Barnwell Bros., Inc, Burlington, N. C.; Consolidated Ifotor Lines, Inc., Hartford, Conn.; Horton Motor Lines, Inc, Charlotte, N. C.; McCarthy Freight System, Taunton, Mass.; M. Moran Transportation Lines, Inc, Bufialo, N. I.; Southeastem Motor Lines, Inc., Bristol, Va.; and Transportation, Inc., Atlanta, Ga. In addition to north-south service, lines will extend west to Pittsburgh, Cleveland and New Orleans. The seven companies operate 3,500 vehicles, have over 6,000 employees, and in 1940 had total operating revenues and net income of $\$ 17,205,23 \$$ and $\$ \$ 50,327$ respactively. The total consideration of approximately $\$ 9,500,000$ is to be allocated so that each combining carrier receives an amount of $6 \%$ cumulative convertible $\$ 100$ par preferred stock equal to $80 \%$ of its net worth, and an amount of common stock equal to $50{ }^{\circ} \epsilon$ of its net income from April, 1940, to April, 1941, after taxes and dividends. See Transport Topics, June 16, 1941, Vol. 15, No. 38, p. 1. 
post-war diversion of rail traffic to motor carriers finally aroused the slumbering railroads to a counter-offensive. Joining forces with those who believed that unregulated interstate motor carriage was imperiling effective state supervision, the railroads launched a serious campaign for federal regulation in 1925. ${ }^{18}$ The fight was no blitakricg. For ten years no session of Congress was free from regulatory proposals; dozens of bills were introduced, hearings were held, and one bill, limited to bus regulation, passed the House. ${ }^{10}$ In the depression following 1929 agitation became more intense, for railroad distress had become acute and, moreover, motor carriers fared little better. The Interstate Commerce Commission, after study, supported federal regulation; ${ }^{20}$ a specially appointed Federal Coordinator of Transportation recommended federal control $;^{21}$ those within the motor carrier industry who hoped regulation would provide a cure for too much competition added their support,${ }^{22}$ and finally Presidential insistence upon legislation, as part of a comprehensive plan of extending federal control to all transport agencies, became more firm. ${ }^{23}$ Under such pressure a bill closely pat-

18. Twin bills were introduced into the first session of the 69th Congress, S. 1734 by Senator Cummins, 67 CoNg. Rec. 904 (1925) and H. R. 8266 by Representative Parker, 67 Cong. REc. 2761 (1926). Although hearings were held on S. 1734 before the Senate Committee on Interstate Commerce, to which the bill had been referred, neither bill was reported out of the Committee. The Cummins-Parker bill was not the first proposal made to Congress for the regulation of interstate motor carriage. In 1909 two such bills were presented to the House: H. R. 1066, 61st Cong., 1st Sess. (1909), introduced by Representative Olcott, 44 Cong. Rec. 58 (1909), and H. R. 5176, 61st Cong., 1st Sess. (1909), introduced by Representative Cocks, 44 Cong. Rec. 390 (1909). Other than these two surprisingly early proposals, however, no other bills preceded the Cummins-Parker bill. For a brief picture of the background, see Henty, The Econoutics of Transportation (1940) 426-30.

19. H. R. 10288, 71st Cong., 2d Sess., 72 Cong. Rec. 6029 (1930). For a summary of the various bills introduced into Congress, in their chronological order, see WAGNer, A Legislative History of the Motor Carrier Act, 1935 (1935) 93-100.

20. Motor Bus and Motor Truck Operation, 140 I. C. C. 685 (1928); Coordination of Transportation, 182 I. C. C. 263 (1932). For various annual reports issued by the Commission to Congress, see, e.g., 44th ANv. Rep. I. C. C. (1930) 75; 45th ANv. Rep. I. C. C. (1931) 101.

21. Eastman, Report of Federal Coordinator of Transportation, SEN. Doc. No. 152, 73d Cong., 2d Sess. (1934) ; Eastman, Report of Federal Coordinator of Transportation, H. R. Doc. No. 89, 74th Cong., 1st Sess. (1935).

22. See, e.g., Hearings Before Senate Committce on Interstate Commerce on S. 1734, 69th Cong., 1st Sess. (1926) ; Hearings Before Honlse Comnittee on Interstate and Foreign Commerce on H. R. 6836, 73d Cong., 2d Sess. (1934); Hearings Before Senate Committee on Interstate Commerce on S. 1629, 74th Cong., 1st Sess. (1935).

23. On January 31, 1935, in a special message to Congress, President Roosevelt stated that he would soon ask for general legislation centralizing the regulation of all transportation agencies. N. Y. Times, February 1, 1935, p. 1, col. 7. In a "firesidechat" on April 28, 1935, the President proclaimed urgent need for the regulation of trucks and busses operating in interstate commerce. N. Y. Times, April 29, 1935, p. 1, col. 8. 
terned after one suggested by the Federal Coordinator and approved by the Commission was enacted on August 9, 1935, to become the Motor Carrier Act of 1935.

The unification provision of the Act, Section 213, entitled "Consolidation, merger, acquisition and control," was modelled on paragraphs (4) and (5) of the old Interstate Commerce Act, of which the Motor Carrier Act became Part II. Section 213(a) set forth the permissible methods of integration and Section 213(b) made those methods exclusive. Explaining generally to the Senate the purposes of Section 213, Senator Wheeler asserted that, although most truck operations were small enterprises, there were rumors of expansions into sizeable systems, and, in view of past experience with railroad and public utility unifications, it was thought necessary to control such developments where the number of vehicles involved was sufficient to make the matter of more than local importance. ${ }^{24}$ The principle of supervised integration caused no dispute and legislative differences were confined to details rather than objectives. One accepted purpose was the protection of motor carriers from railroad domination. As a safeguard, subsection (a) (1) provided that in the ordinary combination of one motor carrier with another motor carrier approval should be granted if the Commission found the transaction "consistent with the public intcrest," but if the applicant was a non-motor carrier, such as a railroad, or was a person controlled by or affiliated with such a carrier, the prerequisite to Commission approval was that the transaction "promote the public interest" by enabling the applicant to use service by motor vehicle to public advantage in its operations, and avoid undue restraint of competition. ${ }^{25}$

Aside from certain procedural improvements ${ }^{20}$ no major change was made in the Motor Carrier Act of 1935 until September 18, 1940, when

This expressed need was formally presented to Congress in a message of June 7, 1935, when the President requested the House to vote favorably on the bill already passed by the Senate. N. Y. Times, June 8, 1935, p. 1, col. 6.

24. 79 Cong. Rec. 5654-55 (1935).

25. The possibility of railroad absorption of motor carriage, to be fostered by regulation by a "railroad minded" Commission, provided an oratorical bludgeon for the opponents of regulation which was utilized by them during debate of all the proposals. That the "railroad proviso" in $\$ 213$ was intended to provide protection against this possibility is clear. Senator Wheeler, speaking for the Committee on Interstate Commerce in explaining S. 1629, 74th Cong., 1st Sess. (1935), stated: "With this limitation, it will be possible for the Commission to allow acquisitions which will make for coordinated or more economical service and at the same time protect the public against the monopolization of highway carriage by rail, express, or other interests." 79 Coxc. REc 5655 (1935). See also a similar statement made to the House by Representative Sadowski, 79 Coxc. Rec. 12206 (1935).

26. A bill providing amendments designed to improve and expedite administration, H. R. 9739 (75th Cong., 3d Sess.), was introduced into the House on March 4, 1938, 83 Cong. Rec. 2897 (1938). On June 16, 1938, the bill was presented to the President, 
the Transportation Act of 1940 became effective. ${ }^{27}$ In substance a revision of the existing Interstate Commerce Act, the Transportation Act of 1940 in its Part III extended Commission control to water carriers, while Parts I and II dealt as before with sail and motor carriers respectively. ${ }^{28} \mathrm{~A}$ formal change was made in the unification provisions by repealing Section 213 of the Motor Carrier Act and removing its provisions to Section 5, Part I, of the Interstate Commerce Act, which in turn was amended to cover unifications of all three types of carriers. Moreover, alterations in language were made, for while Section 5(2) (b) like Section 213 (a) (1) requires unification transactions to be "consistent with the public interest" the proviso against railroad domination was changed slightly. Instead of retaining the requirement that the transaction "promote" the public interest, the phrase "consistent with" the public interest was substituted, but in such a way as to retain the very same meaning. ${ }^{29}$ Thus Section $5(2)(b)$ preserves the guaranty of Section 213(a) (1) against railroad control of motor carriage except

83 Cong. REc. 9707 (1938), and approved on June 29, 1938 to become Pub. L. No. 777, 75th Cong., 3d Sess., 52 Sxat. 1236 (1938), 49 U. S. C. \$§ 303-24 (Supp. 1939).

Among the amendments enacted, $\S 213$ (b) (1) was changed so as to correct an oversight and to specifically include plural acquisitions between motor carriers and other carriers. Of more importance, the mandatory hearing provision for unification cases wats changed so as to permit the elimination of hearings unless the Commission should find a hearing necessary to determine whether or not the findings made by the examiner or joint board were properly made. It was also provided that $\S 213(\mathrm{~b})(2)$ be amended so as to explicitly include general enforcement remedies as well as the hearing and orders provided in that subsection.

27. Pub. L. No. 785, 76th Cong., 3d Sess. (Sept. 18, 1940).

28. Part I of the Interstate Commerce Act now encompasses $\$$ 1-27, Part II, $\$ \$ 201$ 27, and Part III, \$§301-23. As to Part III, see Comment, Regulation of Water Carriers (1941) 50 Y ALE L. J. 654. Provisions contained in Part I will hereinafter be cited as the Interstate Commerce Act.

29. The Motor Carrier Act, $\S 213$, had required that the proposal will "promote the public interest $b y$ enabling such carrier to use service by motor vehicle to public advanttage in its operations and will not unduly restrain competition," while now $\S 5$ of the . Interstate Commerce Act requires a finding that the transactions will be "consistent with the public interest and will enable such carrier to use service by motor vehicle to public advantage in its operations and will not unduly restrain competition." (Italics supplied).

Another change was made in limiting the application of the proviso strictly to "railroads." $\$ 213(a)$ (1) had subjected to the proviso any "carrier as defined in $\S 1(3)$ of this title, or any person which is controlled by such a carrier or affiliated therewith." As interpreted by the Commission, $\$ 1(3)$ included not only railroads and other carriers then subject to Commission jurisdiction but also water carriers which join with railroads in joint tariffs and which engage in continuous transportation of passengers or freight in conjunction with railroads. Puget Sound Nav. Co.-Control, 25 M. C. C. 53 (1939). That this construction is now impossible since the Transportation Act of 1940 became effective has been acknowledged by the Commission. St. Johns River Line Co.Purchase, 36 M. C. C. 338 (1941). 
within a limited sphere. ${ }^{30}$ The only addition to the unification provisions made by the Transportation Act of 1940 is the entirely new Section $5(2)(\mathrm{c})$, providing:

“(c) In passing upon any proposed transaction under the provision of this paragraph (2), the Commission shall give weight to the following considerations, among others: (1) the effect of the proposed transaction upon adequate transportation service to the public; ... (3) the total fixed charges resulting from the proposed transaction; and (4) the interest of the carrier employees affected."

\section{I.C.C. Jurisdiction under Section 5(2)}

The unification provisions of Section 5(2) are fairly simple to outline. Under subsection (a) it is made lawful with Commission approval for two or more carriers to unify their properties and franchises by merger or consolidation, by purchase, lease, or operating contract, or by acquisition of control through stock ownership. ${ }^{31}$ Likewise, a person not a carrier may acquire control of two or more carriers through stock ownership, or, if it already does control one carrier, it may acquire control of another carrier. Then subsection (b) prescribes the procedure and conditions for Commission approval, with subsection (c), set out above, indicating certain relevant considerations to be taken into account by the Commission. That the intent is to make the types of transactions enumerated in subsection (a) the only permissible ones is

30. Representative Bulwinkel, during debate, stated: "The conferees wish to make it plain that it is not their intention, by changing the language of Section 213, hereinbefore quoted [the railroad proviso], to change the legislative intent one iota with respect to the acquisition of a carrier by motor vehicle by a carrier by railroad, and that it is the intention of the conferees that Section 5(2) (b), as amended by Section 7 of the conference report, shall have the same practical application and legal efiect as Section 213(a) (1) as it is now shown in Part II of the Interstate Commerce Act." 86 Cosic. REC. 15583 (1940). In spite of this, and in spite of a similar statement made by Senator Truman, 86 CoNG. REc. 17510 (1940), Senator Shipstead expressed fear that the change in language might well be viewed as a relaxation of the safeguards against railroad invasion of the motor carrier domain. 86 Covg. Rec. 17640-43 (1940).

31. The unification scctions contemplate the transfer of operating rights as well as tangible property. Operating rights, often the principal object in a unification proceeding, constitute more than a "license to operate." Yellow Truck Lines, Inc--Purchase, 35 Mr. C. C. 773 (1940); Hancock Truck Lines, Inc-Purchase, 5 Mr. C. C. 405 (1938); Tri-State Transit Co. of La., Inc-Purchase, 5 Mr. C. C. 317 (1937); Rutherford Frt. Lines, Inc--Purchase, 5 M. C. C. 207 (1937).

While both $\$ 213$ and now $\$ 5$ expressly permit two or more carriers jointly to malie acquisitions, the Commission has made approval of such transactions more difficult to obtain than if joint control were not sought. Clover-Leaf Frt. Lines, Inc--Purchase, 25 M. C. C. 742 (1939); Union Pac. R. R.-Control, 15 M. C. C. 101 (1933). 
clear from Section 5(4) which renders unlawful any effectuation of control in a common interest of two or more carriers in any other way, "however such result is attained, whether directly or indirectly, by use of common directors, officers, or stockholders, a holding or investment company or companies, a voting trust or trusts, or in any other manner whatsoever." 32 Inasmuch as all direct forms of unification are covered by subsection (a), Commission supervision of unifications is complete except where there is a specific exemption, and all indirect but nonetheless effective means of exerting control are outlawed.

A basic principle applied by the Commission in interpreting former Section 213, and equally relevant under Section $5(2)$, is that the unification provisions are wholly "permissive" in nature. That is, in every case, the Commission makes an appraisal of whether or not the proposed unification would be consistent with the public interest without heed to whether it will subsequently fail for other reasons. No assumption will be made that unification authority is likely to prove futile. Consequently, arguments for Commission disapproval on the ground that "grandfather" rights have not yet been granted, or are unfounded or invalid, or that the contract for sale is being controverted, are disregarded as irrelevant and reserved for later disposition by the Commission or by the courts. ${ }^{33}$

Assuming that the transaction proposed falls within the types of unification sanctioned by Section 5(2), Commission jurisdiction in other respects must be established before the merits of the proposal will be considered. A prerequisite for such jurisdiction is that the vendor carrier possess rights to operate interstate. ${ }^{34}$ A carrier may hold such

32. Section $5(5)$ supplements $\S 5(4)$ by carefully defining when control or managcment is effectuated so as to prevent escape from the Act by persons who are not themselves carriers but who are nevertheless affiliated with such carriers. Cf. McEwingControl, 25 M. C. C. 66 (1939); Atlantic Greyhound Corp.-Purchase, 25 M. C. C. 1 (1939).

33. Steffke-Purchase, 36 M. C. C. 371 (1941); Herrin Transp. Co.--Purchase, 35 M. C. C. 88 (1939); Southern Motor Exp., Inc.-Purchase, 35 M. C. C. 85 (1940); English-Purchase, 35 M. C. C. 49 (1939); Consolidated Frt. Lines, Inc-Control, 25 M. C. C. 207 (1939); Raymond Bros. Motor Transp., Inc.-Purchase, 15 M. C. C. 477 (1938) ; Triangle Exp. \& Transfer Co.-Purchase, 5 M. C. C. 797 (1938) ; Brashbear Frt. Lines, Inc.-Control, 5 M. C. C. 218 (1937).

34. Motor Carrier Act, $\S 203(14)$, (15), (16), "Definitions and Exceptions," makes it clear that the phrase "motor carrier" means a carrier, whether common or contract, which operates in interstate commerce. The Commission invariably states that it has no power to authorize the transfer of soleiy intrastate rights. See, e.g., Santa Fe Trail Transp. Co.-Purchase, 5 M. C. C. 115 (1937).

Under $\$ 213$ not only must the vendor be engaged in interstate operations but he must also be a carrier by motor vehicle. Thus, if a vendor were engaged in local pick-up and delivery operations for a railroad, service subject to provisions of Part I of the Act, no 
rights only by reason of Commission approval of an application for a certificate of convenience and necessity or confirmation of rights under the "grandfather" clause. ${ }^{35}$ If no showing is made in the unification proceeding that the vendor still possesses such rights ${ }^{36}$ or, if on the other hand, it affirmatively appears that the Commission has denied vendor's claim to interstate rights, ${ }^{3 \pi}$ or that they have been lost by

\$213 jurisdiction exists. Modesto Interurban Ry.-Purchase, 15 M. C. C. 265 (1938); cf. Cincinnati \& Lake Erie Transp. Co.-Consolidation, 36 MI. C. C. 243 (1940) (one of the proposed acquisitions was a reorganized railroad). Since $\$ 5$ has been broadened to include unification of all carriers subject to Part I, Part II, or Part III, this ground for lack of jurisdiction has been eliminated.

35. The "grandfather" clause is contained in the first proviso of the Motor Carrier Act, $\$ 206(a)$. Under this proviso, a motor common carrier which was in bona fide operation on July 1, 1935, was entitled to a certificate without further showing of convenience and necessity upon filing an application within a specificd period.

The second proviso to $\$ 206(a)$ exempts a carrier engaged in operation solely within a single state, but which carries freight or passengers in interstate commerce, from obtaining a certificate of convenience and necessity. However, by registering with the Commission such carrier may obtain the right to conduct such interstate transportation which the proviso makes otherwise subject to Commission jurisdiction. In a number of cases, one of the earliest being K. \& L. Transp. Co., Inc.-Purchase, 5 MI. C. C. 67 (1937), approval was given to transactions of unification between an interstate carrier and one operating between points within a single state but engaged in interstate commerce under the proviso. In some of the cases, starting with Illinois Greyhound Lines, Inc-Purchase, 15 MI. C. C. 86 (1938), a certificate was ordered issued to the acquiring carrier upon approval of the unification, covering not only the physically interstate operations but also the acquired operations within one state as well. However, this entire doctrine has been repudiated by the Commission in a recent decision which holds that operations conducted under the proviso are not "property" which the Commission can authorize to be transferred under \$5. Baggett Transp. Co.-Purchase, C. C. H. Fed. Carriers Serv. $\llbracket 7736$ (1941).

The textual statement is somewhat misleading, for, because $\$ 5$ is permissive and because the Commission desired to expedite unification proceedings, unifications have been approved after a vendor's application for "grandfather" rights has been filed but before it has been finally decided by the Commission. Brooks Transp. Co., Inc--Purchase, 5 M. C. C. 85 (1937); see also note 33 supra. If vendor's applieation for operating rights is later denied, operation over those routes will then have to be abandoned. However, in Crichton-Purchase, 35 M. C. C. 661,663 (1940), the Commission stated that once the "grandfather" rights have been confirmed in the vendor, ". . . these temporary reasons for assuming the motor-carrier status of a prospective vendor under section 213 are no longer present." After confirmation a showing of continued interstate operation under these rights is required.

36. Applicant must demonstrate that vendor possesses interstate rights even though such rights have once been confirmed by the Commission. Chrispens Truck Lines, IncPurchase, 36 MI. C. C. 343 (1941). Commissioner Porter dissented on the ground that once acquired the proper status should be presumed to continue.

37. Humboldt Motor Stages, Inc-Purchase, 36 M. C. C. 183 (1940) ; Plaza Exp. Co., Inc-Purchase, 35 M. C. C. 447 (1940) ; Burlington Transp. Co.-Lease, 15 M. C. C. 57 (1938); Gordon-Control, 5 11. C. C. 373 (1938). 
abandonment, ${ }^{38}$ or prior sale, ${ }^{39}$ the vendor cannot qualify as a carrier under the Act and the unification application will be dismissed for lack of jurisdiction.

Another ground for exclusion of motor carrier unifications from the provisions of the Motor Carrier Act is the twenty vehicle exemption originally contained in Section 213(e) and removed in 1940 to Section $5(10)$. Where only motor carriers are parties to the unification and "where the aggregate number of motor vehicles owned, leased, controlled or operated by such parties, for purposes of transportation subject to Part II, does not exceed twenty," no grant of authority by the Commission is required. ${ }^{40}$ The aim of this exemption, as its legislative history demonstrates, is to protect combination by small carriers from the "red-tape" incident to Commission approval, ${ }^{41}$ a purpose which has been generally furthered by Commission interpretation. For example, prior to a new general order of June 6, 1940, "vehicles" in Section 213(e) had been construed to mean the total number of physical units

38. Abandonment cases have caused a split in the Commission. The majority has determined that physical operations are a condition precedent to Commission jurisdiction under $\S 213$, and, if the vendor has abandoned operations, an application to purchase those operating rights will be dismissed. Chrichton-Purchase, 35 M. C. C. 661 (1940). In a dissent to that decision Commissioner Porter argued that if it be true that $\$ 213$ is permissive no question concerning the validity of operating rights should be settled in a $\$ 213$ proceeding, and the question of abandonment should be reserved for later determination because it concerns the validity of operating rights. However, the doctrine announced by the majority has been followed in subsequent cases, and without respect to the cause of the abandonment. Silver Fleet Motor Exp., Inc.-Purchase, 1 Fed. Carrier Cases $\Uparrow 7471$ (1940) ; Carlo Transp. Co., Inc.-Purchase, 36 M. C. C. 482 (1941); B. F. Walker, Inc.-Purchase, 36 M. C. C. 361 (1941) ; William C. Barry, Inc--Purchase, 36 M. C. C. 335 (1941) ; cf. Motor Delivery Co.-Purchase, 36 M. C. C. 367 (1941); Marshall-Purchase, 36 M. C. C. 33 (1940). However, if abandonment has caused operating rights to be denied in a prior proceeding, it is agreed that tho Commission has no jurisdiction to authorize a transfer. Riss \& Co., Inc.-Purchase, 35 M. C. C. 383 (1940) ; Krema Trucking Co.-Merger, 25 M. C. C. 85 (1939); Watson Bros. Transp. Co., Inc.-Purchase, 15 M. C. C. 581 (1939).

39. Transohio Motor Frt., Inc.-Purchase, 35 M. C. C. 749 (1940); Watson Bros. Transp. Co., Inc.-Purchase, 15 M. C. C. 581 (1939).

40. Interstate Conmerce Act $\$ 5(10)$. The language used in $\$ 213(\mathrm{e})$ was virtually identical. Many applications have been dismissed because fewer than 20 vehicles were involved. See, e.g., Charlton Bros. Transp. Co.-Purchase, 36 M. C. C. 267 (1940); Phoenix Motor Frt., Inc-Lease, 35 M. C. C. 093 (1940); Webster-Purchase, 25 M. C. C. 393 (1939).

41. "An amendment made by the committee makes this jurisdiction applicable, except in the case of rail, express, or water carrier affiliations, only where the total number of vehicles involved is more than 20 . In other words, we eliminated from this provision such a case, for example, as that of two small operators who might want to get together, and we made it apply only to cases where they had more than 20 vehicles, so that the small operators could get together without the necessity of going through a great deal of red-tape with the Commission." Senator Wheeler, explaining the provisions of S. 1629, 74th Cong., 1st Sess. (1935), to the Senate, 79 Covg. Rec. 5655 (1935). 
-11 trucks, 6 tractors and 6 trailers equalled 23 vehicles. The new rule, however, defined "vehicle" as a complete transportation unit, with available tractors and trailers paired as one vehicle, and in terms of the above illustration only 17 vehicles would be involved.2

The foregoing discussion of the twenty vehicle exemption is misleading, however, in so far as it indicates that a unification so exempted from the requirements of Section 5(2) is entirely free from Commission control. Such a conclusion had been reached by Sharfman, ${ }^{43}$ but apparently he overlooked the provision in Section 212(b), which provides that "except as provided in Section 5 (formerly Section 213), any certificate or permit may be transferred, pursuant to such rules and regulations as the Commission may prescribe." 4 By a general order on July 1, 1938, the Commission did prescribe rules and regulations requiring its approval of transfers of operating rights free from Section 213 because of the twenty vehicle exemption, or for any other reason as well..$^{45}$

The questions of whether the twenty vehicle exemption in Section 5(10) places unifications beyond the reach of Section 212(b) where twenty vehicles or less are involved, and of whether the Commission possesses authority to require its approval as a condition precedent to effective transfers subject to Section 212(b), if ever in real doubt, have been settled by recent litigation. ${ }^{40}$ In July, 1940 the United States filed an information against one Resler, charging that he had engaged in interstate motor carrier operations over a specified route without a certificate of public convenience and necessity. Resler filed a special plea in bar, alleging that he had acquired requisite operating authority from one Brady, to whom it had been granted originally. It was stipulated that not more than twenty vehicles were involved and that Commission approval had not been obtained. On direct appeal from a lower court decision sustaining Resler's plea, the Supreme Court reversed and returned the cause to the district court. Speaking for a unanimous bench Mr. Justice Murphy held that the transfer was clearly subject to Section 212(b) and that the Commission undoubtedly had authority to require its prior consent even to transfers exempted from Section 213.

Unification among small carriers, then, is not completely free from Commission supervision and "red-tape." Indeed, since the elimination in 1938 of the requirement of public hearings under the unification

42. I. C. C., General Order, "Total Number of Vehicles Involved"-Tractor and Semi-trailer as One Unit, June 6, 1940, C. C. H. Fed. Carriers Serv. I1591 (1940).

43. IV Sharfaran, The Interstate Coararerce Commission (1937) 112.

44. Motor Carrier Act \$212(b).

45. I. C. C., General Order, Rules and Regulations Governing Transfers of Rights to Operate as a Motor Carrier in Interstate or Foreign Commerce, July 1, 1938, 3 FED. REG. 2157 (1938).

46. United States v. Resler, 61 Sup. Ct. 820 (U. S. 1941 ). 
provisions, the time-and-money-consuming procedure seems virtually paralleled under Section 212(b) - virtually, but not entirely. A unification subject to Section $5(2)$ requires a showing of consistency with the public interest, while the rules and regulations under Section 212(b) merely demand that the proposed transferee be "fit, willing and able" properly to perform the service authorized and to conform to the provisions of the Motor Carrier Act. Because these latter standards are more easily met, the policy of the Commission is saved from unqualified indictment for defeating the expressed legislative purpose of Section $5(10)$. But even this policy has been apparently jeopardized by langunge in United States $v$. Resler. Mr. Justice Murphy, in justifying the rule requiring Commission approval of a transfer subject to Section 212(b), referred to Sections 206 (a) and 207 (a) pertaining to issuance of certificates of public convenience and necessity, and then stated:

"In many respects a transferee such as appellee stands in the same relation to the Commission as an original applicant for permission to operate. Many inquiries which are relevant to the initial application are equally relevant to the proposed transfer. . . . Plainly the finding of the requisite fitness, willingness and ability of the first applicant is wholly inapplicable to his proposed transferee . . ., and the operations inceptively authorized may no longer serve public convenience and necessity because conditions have changed." 47

Perhaps Mr. Justice Murphy means that the proper test to apply to transfers under Section 212(b) is that of public convenience and necessity. But if so, the transfers excluded from Section 5 are subject to standards more difficult to meet than unifications within the section, for consistency with the public interest has never been construed as equivalent to fulfilling the demands of public convenience and necessity. Certainly such an interpretation would reverse legislative purpose. Or possibly Mr. Justice Murphy means to apply the test of public convenience and necessity to unifications under Section 5 as well as to transfers under Section 212(b). But such a construction would ignore differences in statutory language and repudiate a long line of Commission decisions. Whatever Mr. Justice Murphy means, and it is probable that he was merely confused, this startling and wholly unnecessary paragraph has cast doubts upon a host of Commission cases construing the Motor Carrier Act. Fortunately, doubts created by such a dictum probably will not be sufficient to alter the course of decisions. ${ }^{48}$

47. Id. at 822 .

48. In Baggett Transp. Co.-Purchase, C. C. H. Fed. Carriers Serv. $\llbracket 7736$ (1941), a decision subsequent to United States v. Resler, supra note 46, the Commission stated: "Public convenience and necessity, as we have frequently defined it, ordinarily requires a higher degree of proof than mere consistency with public interest, and usually contemplates an entirely distinct set of circumstances. The issue of public convenience and 


\section{Consistency with the Public Interest}

Consistency with the public interest is the basic criterion for judging a unification transaction, which falls within the types permitted by Section 5(2) (a) of Part I of the Interstate Commerce Act. This test is set forth in paragraph (b) of Section 5(2), which provides for Commission approval:

"If the Commission finds that, subject to such terms and conditions and such modifications as it shall find to be just and reasonable, the proposed transaction is within the scope of paragraph (a) and will be consistent with the public interest." 40

Ever since the Motor Carrier Act went into effect in 1935, the Commission has consistently asserted that a unification transaction may be consistent with the public interest without being required by public convenience and necessity. The latter consideration has been held to relate only to the question of whether or not to issue an original certificate to operate, and has no place in a unification proceeding. ${ }^{5 .}$ Hence, the improvement of motor carrier service by the creation of new through routes or the addition of new schedules, while providing a new type of service, is permitted with little regard to protestations that the area is already adequately served and that additional service will only divert revenue from existing carriers. ${ }^{\text {b1 }}$

necessity is not presented in the normal proceeding under section 5, and not being presented, cannot be decided."

49. Interstate Conmierce Act \$5(2) (b).

50. Horlacher Delivery Serv., Inc.-Purchase, 35 M. C. C. 149 (1940); Herrin Transp. Co.-Purchase, 35 M. C. C. \&S (1939); Elliot-Purchase, 25 M. C. C. 11 (1939); Raymond Bros. Motor Transp., Inc-Purchase, 15 M. C. C. 477 (1938); Spitzer-Purchase, 15 Mr. C. C. 331 (1938); Arrow Carrier Corp.-Purchase, 15 M. C. C. 203 (1938) ; Transamerican Frt. Lines, Inc.-Purchase, 5 M. C. C. 712 (1938); Keeshin Motor Exp. Co., Inc-Leases, 1 M. C. C. 373 (1936). See also note 48 supro.

Some difference in meaning seems demanded by the difference in statutory language used. That is, $\$ 207$, the application section, requires that operations be "required by public convenience and necessity," while $\$ 213$ merely requires the unification to be "consistent with the public interest."

51. The Interstate Commerce Act, $\S 5(2)(c)$, now provides that the Commission in a unification proceeding must consider inter alia "the effect of the proposed transaction upon adequate transportation service to the public." It is doubtiul that this injunction changes Commission considerations in this respect. Cases decided since the new Act became effective have restated the principle that unification considerations are different from those involved in an application proceeding, especially with reference to the creation of new through routes. Steffke-Purchase, 36 M. C. C. 371 (1941); Carolina Frt. Carriers Corp.-Purchase, 36 M. C. C. 251 (1941); Clark-Lease, 36 M. C. C. 195 (1940) ; Mrarshall-Purchase, 36 M. C. C. 33 (1940). It is possible that more attention will be given to diverted traffic and revenue. On the other hand, no application has jet been denied for this reason, and it is worth noting that the question is one of the effect of the unification "upon adequate transportation service to the public." If diversiun had injured adequate service to the public, the application would likely have been declared 
It will be recalled that in the Transport case it was the failure to meet the test of consistency with the public interest which led to the Commission's denial of the application. The four factors there considered were resulting economies and improvements in service, elimination of motor carrier competition, propriety of the consideration and promoters' fees, and simplification of corporate structure. These same factors, to a greater or lesser degree, run through the great mass of motor carricr cases which preceded the Transport case and from them a clearer picture of the Commission's general policy can be drawn.

Economies and Improvements in Service. By reason of paragraph (c) of Section 5(2), added in 1940, the Commission is directed to give weight to the effect of any proposed unification upon adequate transportation service to the public. ${ }^{52}$ Since such a direction does not require an affirmative showing of an improvement in service offered to the public, it probably remains true that a unification transaction can be consistent with the public interest so long as it is "not contradictory or hostile thereto." 53 The Commission, however, perhaps influenced by the previous cases involving railroad unifications, ${ }^{54}$ almost always discovers and relies upon some improvement in the service offered to the public when it finds a unification consistent with the public interest. There is virtually no end to the factors taken into account by the Commission

inconsistent with public interest under $\$ 213$ even without the specific mandate. It would seem, then, that the new Act probably has not changed prior practice in this respect. But note that in two very recent instances considerations of public convenience and necessity seemingly are being taken into account as a basis for disapproval of unifications which may bring about increases in competition and thereby endanger adequate service for the public. Consolidated Freightways, Inc.-Purchase, No. MC-F-1317, Apr. 23, 1941; Consolidated Freightways, Inc.-Purchase, Proposed Report by Examiner Engelhart, No. MC-F-1318, May 27, 1941.

52. Interstate Commerce ACt $\$ 5(2)$ (c).

53. Merchant's Dispatch, Inc.-Purchase, 25 M. C. C. 407 (1939).

54. The Transportation Act of 1920, 41 STat. 481 (1920), permitted railroad unifications when the proposal was "in the public interest." This was changed by the Emergency Railroad Transportation Act of 1933, 48 STAT. 217 (1933), 49 U. S. C. $\$ 5$ (4) (b) (1934) to approval of unifications which "will promote the public interest." Inasmuch as no distinction in the meaning of the two phrases was drawn by the Commission or the courts, the further change of criterion to consistency with public interest, now provided for railroad unifications (INTERSTATE CONIMERCE ACT $\$ 5(2)(b)$, as amended by the Transportation Act of 1940), probably will not alter prior interpretation. The original phrase, "in the public interest," was determined by the Supreme Court to have "direct relation to adequacy of transportation service, to its essential conditions of economy and efficiency, and to appropriate provision and best use of transportation facilities," N.Y. Cent. Secur. Co. v. United States, 287 U. S. 12, 25 (1932). See also, Texas v. United States, 292 U. S. 522 (1934) ; United States v. Lowden, 308 U. S. 225 (1939) ; Fort Worth \& R. G. Ry., Control, Operation, Etc., 217 I. C. C. 659 (1936); Union Pac. R. R.-Unification, 207 I. C. C. 543 (1935); Unification of Lines in Southern New Jersey, 193 I. C. C. 183 (1933) ; Control of Central Calif. Traction Co., 131 I. C. C. 125 (1927) ; Lease of Valley Terminal Ry., Property, 65 I. C. C. 105 (1920). 
in measuring such improvement. New through routes, faster and more frequently scheduled runs, better equipment, and economies effected by elimination of duplicate routes, terminal facilities and administrative staffs, and by large scale purchasing, are reasons frequently adduced for approval of unifications. ${ }^{55}$ Reliance is also placed upon more balanced loadings, more direct relations with and responsibility to regulatory authorities, improved financial backing, and guarantees of continued operation by the vendee where otherwise the vendor might become banl:rupt or abandon operations because of ill health or some pressing personal matter. ${ }^{56}$ In finding consistency with the public interest the Commission significantly does not require that any sarings resulting from a unification be passed on to the public in the form of lower rates. Currently it views the problem as one of achieving internal stability and minimum rates rather than as one of protecting the public from exorbitant charges. ${ }^{57}$ Should conditions change, however, it is possible that the Commission might require lower service costs as a necessary incident to unification.

Undue Elimination of Competition. Although former Section 213 contained no express provision against the elimination of competition, except in the proviso applicable to rail carriers acquiring motor carriers, the Commission held that undue elimination of competition was inconsistent with the public interest. ${ }^{58}$ Nor does Section $5(2)$ furnish any

55. Cleveland, Columbus \& Cincinnati H'w'y, Inc.-Purchase, 36 M. C. C. 325 (1941); Lee Way Motor Frt., Inc-Purchase, 36 Ar. C. C. 322 (1941); Gateway City Transfer Co., Inc-Purchase, 36 MI. C. C. 297 (1940); Boss-Linco Lines, Ine-Consolidation, 36 M. C. C. 272 (1940); Carolina Frt. Carriers Corp.-Purchase, 36 MI. C. C. 259 (1940); Yellow Cab Transit Co.-Purchase, 36 M. C. C. 239 (1940); Campball Sixty-Six Exp., Inc--Purchase, 36 M. C. C. 209 (1940); Liberty Trueking Co.-Purchase, 36 M. C. C. 203 (1940).

56. Red Star Exp. Lines of Auburn, Inc-Purchase, 36 AY. C. C. 355 (1941) ; Great Southern Trucking Co.-Purchase, 36 M. C. C. 350 (1941) ; Western Truck Lines-Purchase, 36 MI. C. C. 347 (1941); Merillat-Purchase, 36 Mr. C. C. 331 (1941); Arlaansas Motor Frt. Lines, Inc-Purchase, 36 M. C. C. 264 (1940); Bos Truek: Lines, Ine.Purchase, 36 M. C. C. 216 (1940); Consolidated Copnerstate Lines-Merger, 36 M. C. C. $159(1940)$.

57. "In the railway industry, it was the original purpose of regulation to prevent monopolistic price increases by establishing maximum rates. In the truching industry, it is the apparent purpose of regulation to prevent competitive price reductions by estab-

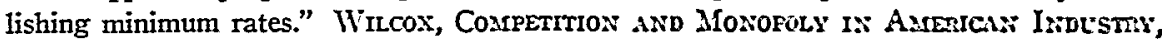
T. N. E. C. AIonograph 21 (1940) 268. In pursuit of this policy the Commission has established minimum rates in many areas, invoking a power seldom used for railway rates. Trunk Line Motor Carrier Rates, 24 M. C. C. 501 (1940); Mriddle Atlantic States Motor Carrier Rates, 10 M. C. C. 193 (1938); New England Territory Commodity Rates, 8 M. C. C. 387 (1938) ; Central Territory Motor Carrier Rates, 8 M. C. C. 233 (1938).

58. Richmond-Greyhound Lines, Inc.-Control, 35 MI. C. C. 555 (1940); Eastern Michigan Transp. Corp.-Control, 25 11. C. C. 483 (1939); Northland-Greyhuund Lines, Inc--Purchase, 5 M. C. C. 123 (1937). 
more express guarantee against restraint of competition than former Section $213 .{ }^{50}$ Any unification of competing carriers by its very nature reduces competition of a kind, just as any commercial contract is a restraint of trade. ${ }^{60}$ But under the Motor Carrier Act, as under the Sherman Act, something more is necessary for condemnation. The boundaries of the doctrine of illegal restraints are flexible and uncertain; given the same facts reasonable men may and do differ, as in the Transport case. Some elimination of competition may be compatible with the public interest; apparently, only when monopoly is approximated is the public interest deemed in jeopardy and the restraint of competition regarded undue. With motor carriage, an industry characterized by severe competition, it is only rarely that such a condition of monopoly is ever approximated.

There have been only three disapprovals of proposed motor carrier unifications, the Transport case excepted, on the ground of undue elimination of competition. ${ }^{61}$ All three of these cases were later reversed, two after reconsideration of this very factor. ${ }^{62}$ The first of these cases, Northland-Greyhound Lines, Inc. ${ }^{63}$ - often called the Liederbach case-involved an application by Northland-Greyhound, which operated between Chicago and Minneapolis-St. Paul via Wisconsin, to purchase its only through-route competitor. The Commission disapproved the purchase, principally because it found the elimination of competition undesirable. ${ }^{64}$ Commissioner Eastman dissented on the ground that potential competition and competition provided by railroad and private car were adequate protection against monopoly. Almost two years later upon a renewal of the application, the Commission adopted Commissioner Eastman's view completely and approved the purchase. ${ }^{65}$

59. INTERSTATE COMMERCE Act $\$ 5(2)$; cf. note 51 supra.

60. This is not to say that the elimination of a competitor by absorption necessarily reduces the effectiveness of competition if other competitors remain in the field. See, c.g., Chamberlin, The Theory of Monopolistic Competition (3d ed. 1938) paśsim.

61. Northland-Greyhound Lines, Inc.-Purchase, 5 M. C. C. 123 (1937); Eastern Michigan Transp. Corp.-Control, 25 M. C. C. 483 (1939); Richmond-Greyhound Lines, Inc.-Control, 35 M. C. C. 555 (1940). Cases concerning acquisitions by another carrier or a motor carrier owned by or affiliated with such other carrier are not included. For such cases, see note 151 infra.

62. Northland-Greyhound Lines, Inc.-Purchase, 25 M. C. C. 109 (1939) (reversing on ground of no undue elimination of competition) ; Eastern Michigan Transp. Co.Control, 36 M. C. C. 413 (1941) (reversing for reason stated in note 66 infra); RichmondGreyhound Lines, Inc.-Control, No. MC-F-119, June 11, 1941 (reversing on ground of no undue elimination of competition).

63. Northland-Greyhound Lines, Inc.-Purchase-Liederbach, 5 M. C. C. 123 (1937).

64. Id. at 125.

65. Northland-Greyhound Lines, Inc.-Purchase, 25 M. C. C. 109 (1939). The Commission at 112 stated: "In view of the competition which the railroads and private automobiles are offering and will continue to offer, Northland will have sufficient difficulty in maintaining safe, attractive, and economical service even if Liederbach's competition is 
Shortly after the reconsideration of the Northland-Greyhound case, the Commission denied authority for Greyhound Corporation to acquire control of a competitor in the southern Michigan region for the reason that it would extend to Greyhound a virtual monopoly of bus transportation within that area. ${ }^{60}$ The Northland-Greyhound case was distinguished on the ground that here railroad interests and Greyhound interests were too interwoven to be deemed competitive. This combination, thought the Commission, threatened to block independent motor competition in the area where otherwise a strong independent bus carrier could easily be supported. ${ }^{67}$

The last and most interesting case in this series, Richmond-Greyhoussd Lines, Inc., was first decided by Division 5 in June, 1940, and was reopened and reversed a year later by the full Commission. ${ }^{\text {gs }}$ The region served extended from Norfolk, Virginia to Richmond and points north, principally Washington and Baltimore. Both applicant and vendor possessed rights to carry passengers between these points, but over routes which were complementary rather than duplicate. The contrast between the earlier decision denying authority and the later one granting it is so sharp that a discussion of both is warranted. In the original decision it was felt that approval of the application would afford Greyhound interests "a monopoly of bus transportation to Norfolk, except over routes south through North Carolina," and that these remaining routes were so extremely circuitous as to offer no effective competition. This possibility of monopoly alarmed the Commission and the application was denied squarely on the point that the threatened undue restraint of competition was inconsistent with the public interest. The reconsidered Northland-Greyhound case was distinguished on two grounds : first, the slowness, expensiveness and inconvenience of railroad service to Norfolk, and second, the reluctance of Virginia regulatory authorities to sanction a second bus operation after authorization of a first one. This latter impediment, coupled with that of meeting a large and well-established competitor, was deemed

eliminated . . . The automotive era has imposed a ceiling beyond which carriers' iares cannot be projected profitably, and a standard of service below which carriers dare not fall. Moreover, regulatory commissions may at any time, upon a showing of public convenience and necessity, authorize another operation."

66. Eastern Michigan Transp. Corp.-Control, 25 M. C. C. 483 (1939). This case has since been reversed, 36 MI. C. C. 413 (1941), not because of a change in attitude toward restraint of competition, but because the Commission decided that the applicant already had control of the carrier to be acquired through an intermediate holding company.

67. Mr. Eastman, for reasons he had advanced in the Northlos:d-Grcyhousd case, again dissented. Eastern Michigan Transp. Corp.-Control, 25 XI. C. C. 483,490 (1939).

68. Richmond-Greyhound Lines, Inc-Control, 35 Af. C. C. 555 (1910) (Division 5 consisted of Commrs. Eastman, Lee and Rogers: Commissioner Eastman dissented), reversed by the full Commission in No. MC-F-119. June 9, 1941 (Cummrs. Porter and Rogers dissented; Commissioner Lee did not participate). 
to make the hazards so formidable that no new competitor would seek to enter the area even if the Commission at a later date desired to issue a new certificate of convenience and necessity. In concluding, the Commission endeavored to draw a sharp distinction between competition within the motor carrier field and that afforded by other methods of transportation, and voiced a strong desire to maintain competition between motor bus operators rather than to rely upon competition from other types of transportation facilities. Such a policy it deemed to be the best protection against undesirable monopoly. ${ }^{60}$

The reversal of the Richmond-Greyhound case was a complete aboutface on the issue of competition so far as the circumstances of the particular case were concerned. Pointing out that applicant and vendor competed at only six terminal points, all of which except Norfolk would continue to have competitive service, the Commission gave its approval with little explanation other than this statement:

"It is our opinion that the traveling public in the entire territory served by Peninsula (the vendor) should not be deprived of the later-mentioned benefits simply because such approval possibly would result in some elimination of competition." 70

Since virtually all the "later-mentioned benefits" were present in the original proceeding, there can be little doubt but that the attitude of the full Commission toward restraint of competition is considerably milder than that of the majority of Division 5. Indeed, it can be said that

69. Richmond-Greyhound Lines, Inc--Control, 35 M. C. C. 555 (1940), quoting with approval from another case: "Competition from within the field of one's endeavor is one thing; that from without is quite another . . . Thus, competition from without is met by the inherent advantages of a possibly inferior service, and the operator thrives while the patrons are denied that ultimate in service and convenience which they have a right to expect and which would be fostered by direct competition from within the field of endeavor."

Commissioner Eastman's dissent to the original Richmond-Greyhound decision is the fullest articulation of his contrary view toward monopoly in the motor carrier field. Doubting the majority's view that regulated monopoly within the industry was necessarily undesirable, he contended that motor carriers face competition more prevalent than ever before. Agreeing that strong competition, for reasons other than the danger of monopoly, would be preferable to national domination of bus transportation by Greyhound, he expressed his belief that the particular transaction before the Commission was not of "crucial importance" in furthering the likelihood of such domination. Pointing out the general undesirability of duplicate operations and the need of absorbing the vendor into an efficient system, he could find no proof that immediate benefits in terms of improved service would be overcome by ultimate unfortunate consequences. Id. at 568 .

70. See Richmond-Greyhound Lines, Inc.-Control, No. MC-F-119, June 9, 1941, at 5. The Commission also conditioned its approval upon renewal by the applicant of an offer made at the date of the original decision to sell to protestants one of the vendor's routes into Norfolk, thereby creating the possibility, at least, of competition at that terminal point. 
to date no unification has been permanently blocked solely because of the danger of monopoly. ${ }^{7 x}$

The most striking feature of these cases in which the Commission has been obliged to deal with the elimination of competition is that all involved bus transportation, and in each case the applicant was a member of the Greyhound system. When confronted with a unification either of busses or trucks, the Commission in other cases, again excepting the Transport case, has been almost eager to discount elimination of competition, even when the combination unified all motor competitors within a given area. ${ }^{\text {i2 }}$ In those cases the Commission has accepted as valid the arguments of potential competition from other motor carriers through the issuance of a new certificate to operate and of almost ever-present railroad and private carrier competition. Hence, these vacillations over Greyhound expansions would seem to stem not from a wish to insure motor competition per se within an area so much as from indecision as to the extent to which that area should be protected from a certain kind of monopoly, namely, "big" monopoly.

Propriety of Consideration. In every motor carrier unification, whether consummated by purchase, acquisition of control, or merger or consolidation, the propriety of the amount of consideration must be established, and also the fitness of the form of payment. In the absence of such a showing the Commission may upset a transaction under Section 5 (2) (b) as inconsistent with the public interest on the ground that its terms are not "just and reasonable." 33 The consideration problem is essentially one of property valuation and its solution is especially diffi-

71. In another decision, Southwestern-Greyhound Lines, Inc-Purchase, No. MICF-1257, June 11, 1941, handed down the same day as the reversal in Richnsond-Groyhoussed Lines, Inc., the Commission by Division 4 approved the purchase by a difierent Greyhound subsidiary of the operating rights of its only competitor between Amarillo, Tesas, and Raton, N. 11. Protests on the basis of undue restraint of competition were overruled on the grounds that there was insufficient traffic over the route to support two efficient carriers, that there would not be any substantial adverse effect unon the protesting carriers, and that improved service to the public would result. Commissioner Porter, in a vigorous dissent, attacked the majority's reasoning and expressed grave concern that the transaction was just another step toward the creation of "big" bus monopoly.

72. Blue Way Trailways, Inc.-Purchase, 35 M. C. C. 763 (1940); Dalby Motor Frt. Lines, Inc-Purchase, 35 M. C. C. 619 (1940); Fleming-Purchase, 35 M. C. C. 607 (1940); Ramos-Control, 35 A. C. C. 9 (1939); Whitney-Purchase, 5 M. C. C. 593 (1938); Reddish-Purchase, 5 M. C. C. 581 (1938); Germann Bros. Arotor Transp., Inc-Purchase, 5 M. C. C. 514 (1938); Bowen Motor Coaches-Purchase, 5 M. C. C. 385 (1938) ; Peoples' Frt. Line, Inc.-Purchase, 5 11. C. C. 296 (1937).

73. This has been the construction placed upon $\$ 5(2)(b)$ by the Commission. The precise statutory language is that if the Commission finds that, "subject to such terms and conditions and such modifications as it shall find to be just and reasonable, the proposed transaction . . . will be consistent with the publie interest," it shall give its approval. 
cult in the case of motor carriers where physical property is so much less important a factor than in the bulk of the transportation industry. With no investment in right of way, the chief tangible assets of a motor carrier are its vehicles and, to a lesser extent, its terminal facilities, neither of which are large in contrast with the same items for rail and water carriers. ${ }^{74}$ On the other hand its intangible property, principally operating rights, and to a lesser extent good will and going concern value, ${ }^{75}$ plays a relatively much more prominent role than with other carriers. Thus the proper relation of the total consideration paid to the intangible property acquired is one of the most critical issues in motor carrier unification.

The position of the Commission on valuation of intangible property is not entirely clear and many contradictions, superficially at least, can be found in the cases. In the Transport case, it will be recalled, the condemned transaction involved a total consideration of over $\$ 22,000,000$, of which more than half was in payment for operating rights of the various carriers. ${ }^{76}$ Emphasizing this fact, the Commission specifically found that the proposed total capitalization was not supported by intangible assets nor by past nor prospective earnings. Moreover, it flatly stated that these elements afforded, in the case of motor carriers, even less justification as a basis for capitalization than they did with rail carriers. ${ }^{77}$ Thus the opinion, standing alone, opens up the old question of what value may be attached to intangible property in acquisition proceedings.

The decision obviously does not mean that no consideration may be paid for operating rights acquired inasmuch as the Commission has approved an overwhelming proportion of applications where intangible elements of value have been recognized. Substantial payments have been permitted for physical property and for operating rights where the latter

74. The Commission has recognized this distinguishing factor. See Union Bus Lines, Inc--Purchase, 5 M. C. C. 201, 205 (1937); 54th ANv. REP. I. C. C. (1940) 32. But $c f$. The Transport Co.-Control, 36 M. C. C. 61,91 (1940).

75. In property valuation doctrine, the elements of intangible value generally regarded as being involved are franchise value (corresponding to value of operating rights here), good will value (which has played little part in motor carrier valuation), and going concern value, the last named being regarded as theoretically distinct from the first two. In public utility rate making cases the United States Supreme Court has raised serious doubt as to this separate going concern value, both in failing to define it in any understandable fashion and to set up any means for determining its existence and amount. See 2 Bonbright, Valuation of Property (1937) 1142-51. In Public Serv. Interstate Transp. Co.-Purchase, 5 M. C. C. 735 (1938), the Commission said that going concern value was merely "a talking point, without substance or evidentiary valuc, and is not helpful."

76. See p. 1379 supra. infra.

77. See The Transport Co.-Control, 36 M. C. C. 61,91 (1940). See also p. 1403 
item has been the larger. ${ }^{78}$ Even more striking are the numerous cases where like payments have been sanctioned for operating rights unaccompanied by any transfer of tangible assets. ${ }^{70}$ In terms of both results and specific language the Commission has clearly recognized that the right to operate over a certain route possesses a commercial value which must be paid for in an acquisition, and that this value may to some extent be estimated by past and prospective earnings. It should be noted, however, that the existence of past earnings is not a requisite, for intangible value has been recognized even where no past earnings existed. ${ }^{89}$

In drawing generalizations from cases where approval has been given, - and reserving for subsequent discussion cases where unification authority has been denied, it should be remembered that each case stands to a large extent upon its own facts. The Commission's approach, after analysis of the financial statements of both the vendor and acquiring carrier, is first to reach a conclusion as to the justification of the proposed purchase price on the basis of earnings. Due weight is given to past earnings of the vendor and even more to estimated future income of the acquiring carrier on the assumption of the completion of the acquisition. ${ }^{81}$ In this latter respect innumerable variables, some of which are also relevant to establish consistency with the public interest in other respects, have been taken into account, including management ability of the acquiring carrier, ${ }^{82}$ prospective economies, ${ }^{83}$ character of the

78. United Truck Lines, Inc-Purchase, 35 MF. C. C. 705 (1940) (consideration $\$ 17,000$, intangibles $\$ 9,000)$; Herrin Transp. Co.-Purchase, 35 AI. C. C. \&S (1939) (consideration $\$ 17,375$, intangibles $\$ 14,500$ ); Crichton-Purchase, 25 M. C. C. 783 (1939) (consideration $\$ 22,519$, intangibles $\$ 13,064)$; Gay's Exp., Inc.-Purchase, 25 11. C. C. 716 (1939) (consideration $\$ 6,000$, intangibles $\$ 5,200$ ); Keeshin Transcon. Frt. Lines, Inc.-Control, 5 MI. C. C. 25 (1937) (consideration $\$ 250,000$, intangibles $\$ 186,811$ ).

79. Crown Coach Co.-Purchase, 36 M. C. C. $144(1940)(\$ 65,000)$; Luper Transp. Co. of Okla.-Purchase, 36 M. C. C. 17 (1940) $(\$ 17,500)$; Cooperative Bus Co.-Purchase, 25 MI. C. C. 793 (1939) (\$18,500) ; Buckingham Transp. Co. of Colo.-Purchase, 25 M. C. C. 667 (1939) $(\$ 15,000)$; Brooks Transp. Co.-Purchase, 5 II. C. C. 85 (1937) $(\$ 115,000)$.

80. Crown Coach Co.-Purchase, 36 M1. C. C. 144 (1940) ; Century System, Ine.Purchase, 35 MI. C. C. 97 (1940); East Texas Mrotor Frt. Lines-Purchase, 25 M. C. C. 779 (1939); Buckingham Transp. Co. of Colo.-Purchase, 25 M. C. C. 667 (1939); Virginia Carolina Coach Co.-Purchase, 1 M. C. C. 309 (1936).

81. Horlacher Delivery Serv., Inc-Purchase, 35 Ar. C. C. 149 (1940); if. Greyhound Corp.-Merger, 36 M. C. C. 397 (1941); Kittrell-Control, 35 M. C. C. 25 (1939); Virginia Carolina Coach Co.-Purchase, 1 M1. C. C. 309 (1936). The relevance of these factors is better shown in the denial cases cited notes 104 and $105 \mathrm{infra}$.

82. Mid-States Frt. Lines, Inc, 36 M. C. C. 1 (1940); Bowen-Control, 25 M. C. C. 683 (1939); Santa Fe Trail Transp. Co.-Control, 5 M. C. C. 81 (1937); ef. Century System, Inc--Purchase, 35 M. C. C. 97 (1940).

83. Crown Coach Co.-Purchase, 36 Mr. C. C. 144 (1940) ; Burlington Transp. Co.Purchase, 5 M. C. C. 291 (1937); Virginia Carolina Coach Co.-Purchase, 1 M. C. C. 309 (1926). 
vendor's routes in relation to the acquiring carrier's existing system, ${ }^{84}$ population tendencies in the territory served, ${ }^{85}$ and many others. From this evidence there is not the slightest doubt but that the Commission has accepted the proposition that operating rights may be more valuable to an acquiring carrier than they were in the hands of the vendor. ${ }^{80}$ Then secondly, and related to the earnings basis, the Commission determines whether the price involved is so large that the financial security of the acquiring carrier may be endangered and public service thereby jeopardized. ${ }^{87}$ In this connection the size of the acquiring carrier has been deemed relevant. ${ }^{88}$ Finally, the Commission takes into account more general factors such as possible public benefit in the form of improved transportation service.

The Commission is concerned with the medium of payment as well as with the amount of consideration, especially in view of Section 5(2) (c) which enjoins it to give proper weight to the fixed charges resulting from the proposed acquisition. ${ }^{80}$ This problem has not been particularly acute, since in most cases where approval has been given the purchase price has been cash, a fact which has been influential in otherwise doubtful cases. ${ }^{00}$ While in several denial cases the increase in the acquiring carrier's fixed charges has afforded the basis for the Commission's action, ${ }^{01}$ several other acquisitions have been approved where a major part of the price was to be paid in installments maturing over varying periods, in one instance as long as eleven years. ${ }^{92}$ In one case the Commission found the increase

84. Crown Coach Co.-Purchase, 36 M. C. C. 144 (1940); Horlacher Delivery Serv., Inc.-Purchase, 35 M. C. C. 149 (1940); Cooperative Bus Co.-Purchase, 25 M. C. C. 793 (1939) ; Shawmut Transp. Co., Inc.-Purchase, 25 M. C. C. 686 (1939); cf. Marion Trucking Co., Inc.-Purchase, 36 M. C. C. 430 (1941).

85. Public Serv. Interstate Transp. Co.-Purchase, 5 M. C. C. 735 (1938).

86. Cooperative Bus Co.-Purchase, 25 M. C. C. 793 (1939); Virginia Carolina Coach Co.-Purchase, 1 M. C. C. 309 (1936).

87. Harris Transp. Co.-Purchase, 35 M. C. C. 88 (1934); New England Greyhound Lines, Inc.-Purchase, 25 M. C. C. 771 (1939). This principle is brought ont much more forcibly in the denial cases, cited notes 104 and 105 infra.

88. Public Serv. Interstate Transp. Co.-Purchase, 5 M. C. C. 735 (1938).

89. While this explicit direction was inserted in the statute only in September, 1940, when $\S 213$ was replaced by $\S 5(2)$, the Commission had considered this factor since the beginning of its administration of the Act.

90. See, e.g., New England Greyhound Lines, Inc.-Purchasc, 25 M. C. C. 771 (1939).

91. The leading case is Union Bus Lines, Inc.-Purchase, 5 M. C. C. 201 (1937), discussed p. 1402 infra. Also applicable are Buckingham Transp. Co. of Colo., Inc.Purchase, 36 M. C. C. 313 (1940); Hill Bus Co.-Purchase, 36 M. C. C. 250 (1940); Kendall-Control, 5 M. C. C. 563 (1938); Pacific Frt. Lines-Purchase, 5 M. C. C. 502 (1938).

92. Crown Coach Co.-Purchase, 36 M. C. C. 144 (1940) (11 years); Luper Transp. Co. of Okla.-Purchase, 36 M. C. C. 17 (1940) (4 years); Red Star Exp. Lines of Auburn-Purchase, 36 M. C. C. 355 (1941) (11/2 years); Watt-Purchase, 35 M. C. C. 
in fixed charges not contrary to the public interest in view of the vendor's past earnings record. ${ }^{93}$ In another, however, where no such evidence existed, the Commission approved the acquisition and the increase in fixed charges with no explanation other than the statement that consideration had been given to Section $5(2)(c){ }^{94}$

One further matter remains before passing on to the denial cases. While substantial payments for operating rights and other intangible property have been permitted, the Commission has been wary of the effect of such acquisitions on the assets accounts of the acquiring carrier. Fearing that undue increases in carriers' "Intangible Property" accounts, which it has characterized as reflecting "fictitious asset positions," might prove detrimental to the sound economic development of the industry, it adopted at the very beginning the policy of requiring such increases to be amortized or otherwise written off. ${ }^{95}$ The development of this policy is itself illuminating. In the initial case establishing this requirement, the Commission simply conditioned its approval on amortization from earnings of the amount of the increase in intangible property. ${ }^{96}$ In subsequent cases it was generally required that such an increase be amortized over a definite period, usually five or ten years, or, in the alternative, that a proportionate amount of the increase be written off to surplus each year. ${ }^{97}$ More recently the policy has tended to become stricter, and immediate write-off to surplus of the amount of increase is now often the rule, if the financial position of the acquiring carrier so permits. ${ }^{38}$ In this fashion the Commission has consider-

755 (1940) (2 years) ; Pacific Motor Trucking Co.-Control, 35 Ar. C. C. 353 (1940) (5 years) ; System Frt. Service-Purchase, 35 M. C. C. 29 (1939) (43. years); KittrellControl, 35 M. C. C. 25 (1939) (5 years); Crichton-Purchase, 25 11. C. C. 783 (1939) (2 years); Johnson-Purchase, 25 M. C. C. 663 (1939) (5 years).

93. Greyhound Corp.-Merger, 36 MI. C. C. 397 (1941).

94. Luper Transp. Co. of Okla.-Purchase, 36 MI. C. C. 17 (1940).

95. The Commission's explanation of this write-off policy is that the "artificial" asset position otherwise created might later be used as a basis "to secure credit, or cited as a justification for future issues of securities." Consolidated Freightways, Inc.-Lease, 25 M. C. C. 723 (1939). The Commission has also been influenced by the experience in railroad and public utility expansions, where "ill-advised purchases of properties or controlling interests therein at extravagant and unwarranted prices in connection with the building up of large systems" had rather unfortunate consequences. Union Bus Lines, Inc--Purchase, 5 M. C. C. 201, 204 (1937).

96. Virginia Carolina Coach Co.-Purchase, 1 M. C. C. 309 (1936).

97. See, e.g., Herrin Transp. Co.-Purchase, 25 M. C. C. 710 (1939); Blue Way Trailways, Inc-Merger, 25 M. C. C. 735 (1939); Cantlay \& Tanzols, Ine.-Purehzse, 25 M. C. C. 756 (1939); Mid-States Frt. Lines, Inc-Consolidation, 36 M. C. C. 1 (1940) ; Main Trucking Co., Inc-Purchase, 36 Mf. C. C. 430 (1941).

98. For example, in Carolina Norfolk Truck Line-Purchase, 30 M. C. C. 104 (1941), the Commission held that in view of the acquiring carrier's surplus "no undue hardship would ensue if the amount so recorded (intangible value) were immediately charged off to surplus." For like instances, see Greyhound Corp.-Merger, 30 MI. C. C. 
ably tempered its recognition of intangible property values in acquisitions.

The denial cases, in contrast to the approval cases, are generally: more emphatic and precise, so much so that unless one bears in mind the results in the latter, a distorted picture of the Commission's policy may easily be drawn. The leading denial case, at least prior to the Transport case, was Union Bus Lines, Inc., decided in 1937.00 There one Bowen, an established motor carrier, organized a new corporation which sought to acquire for $\$ 225,000$ the physical assets and operating rights of another carrier in order to incorporate them into his system. $\$ 25,000$ of the purchase price was to be paid in cash and the $\$ 200,000$ balance in ten year interest bearing obligations. The value of the vendor's tangible property was only $\$ 16,000$ and its average net income for 1934-1936 had been approximately $\$ 11,000$, or slightly over a $5 \%$ return on $\$ 225,000$. With full realization that operating rights had a commercial value and that it should not be too rigorous in its requirements, and despite the past earnings of the vendor and Bowen's alleged ability to utilize vendor's routes in his system with increased financial success, the Commission disapproved the application. Citing the uncertainties of motor carrier earnings and Section $216(\mathrm{~h})$ which precludes consideration of intangible values in rate making, ${ }^{100}$ and placing particular emphasis on the dangers of financing expansion by increases in indebtedness, the Commission found that payment of an amount thirteen times the tangible property value of the acquired assets was clearly excessive. In summing up, the Commission said:

"If transactions of this character are to be approved and become at all common and widespread, the burden which they will place upon the motor-carrier industry must be obvious. The investment in operating rights, which initially cost little or nothing, will vastly exceed the investment in physical property actually used in conducting the operations. We are unable to believe that such a situation is healthy or should be permitted to develop." 101

397 (1941) ; C. \& D. Motor Delivery Co.-Purchase, 36 M. C. C. 367 (1941) ; Red Star Exp. Lines of Auburn, Inc.-Purchase, 36 M. C. C. 355 (1941); Great So. Trucking Co., Inc.-Purchase, 36 M. C. C. 350 (1941); Merillat-Purchase, 36 M. C. C. 331 (1941); Hoover Motor Exp. Co.-Purchase, 35 M. C. C. 639 (1940).

99. Union Bus Lines, Inc.-Purchase, 5 M. C. C. 201 (1937).

100. The use of $\$ 216(\mathrm{~h})$ in this regard is one of the anomalies in the Commission's administration of the Act. Section $216(\mathrm{~h})$ provides that in rate proceedings "there shall not be taken into consideration or allowed as evidence of value of the property of such carrier, either good will, earning power, or the certificate under which stch carricr is operating." In almost every case where an application has been denied on the basis of excessive value for intangibles, $\$ 216(\mathrm{~h})$ is cited, but with little attempt at explanation. At the same time in an overwhelming number of approval cases value has been recognized for operating rights upon their transfer, and earning power has been taken into account.

101. Union Bus 'Lines, Inc.-Purchase, 5 M. C. C. 201, 206 (1937). 
In the Transport case the Commission refused to approve an acquisition where the total consideration was only slightly over two times the value of tangible assets to be acquired. While that decision involved too many factors to rest squarely on any single point, and in particular can be partially explained on the lack of arms-length bargaining in the truest sense, ${ }^{102}$ the following language of the Commission is very pertinent:

"We have found that intangible assets and earning power are not a proper basis for capitalization of rail carriers. . . There is even less justification for issue of securities by motor carriers on the basis of past earnings, as the position of the motor-carrier industry in the transportation field is not yet fully developed. This is particularly true in connection with motor-carrier service such as is here contemplated, much of which would be competitive with rail and water service, and the earnings from which may be adversely affected by any change in the rates of competing forms of transportation. . . Issue of securities to the public on the basis of past earnings of motor carriers may well lead to financial difficulties which will adversely affect their credit and ability to furnish adequate service, as well as cause loss to security holders." 103

The remaining denial cases substantiate the above conclusion that the two principal grounds for Commission disapproval are excessive payments for intangible property and increases in an acquiring carrier's obligations, either of which may impair ability to render adequate motor carrier service. Where excessive consideration alone has been the basis of a denial, the acquiring carrier's financial position has usually been extremely weak and the vendor's property has had a poor earnings record. ${ }^{104}$ Where both grounds exist in a single case disapproval can be regarded as a foregone conclusion. ${ }^{105}$ The border line cases, however, are those where the denial rests principally upon increases in fixed charges, as in Union Bus Lines, Inc. ${ }^{100}$ To some extent this single factor

102. That is, the Commission felt that the underwriter, while theoretically the purchaser, was not buying with its own funds but with those of investors and, consequently, the same restraint was not present as in commonplace vendor-vendee transactions. See The Transport Co.-Control, 36 MI. C. C. 61, 90-91 (1940).

103. The Transport Co.-Control, 36 M. C. C. 61, 91 (1940).

104. Buckingham Transp. Co. of Colo., Inc.-Purchase, 36 M. C. C. 313 (1940); Potashnick Truck Serv., Inc-Control, 5 21. C. C. 723 (193S); ef. Gray Line Motor Tours, Inc-Control, 15 M. C. C. 326 (1938).

105. Hill Bus Co.-Purchase, 36 MI. C. C. 250 (1940) ; Pacific Frt. Lines-Purchase, 5 MI. C. C. 502 (1938); Kendall-Control, 5 M. C. C. 563 (1938); cf. Temple-Control, C. C. H. Fed. Carriers Serv. โ7725 (1941). In two other denial cases, the Cummission was influenced by improper appraisals of physical properties, Public Serv. Interstate Transp. Co.-Purchase, 36 M. C. C. 377 (1941), and by impossibility of determining what was the actual amount of consideration involved, Consolidated Freightways, Inc.Lease, 25 M. C. C. 723 (1939).

106. See discussion p. 1402 stpra. 
serves to distinguish certain denial cases from the great mass of approval cases. But that it is not an infallible touchstone is demonstrated by the several cases already referred to where the Commission has sanctioned acquisitions involving increases in fixed charges with little or no attempt at explanation. ${ }^{107}$

Viewing the denial and approval cases together, it appears that at one extreme the Commission has firmly denied unification applications where the consideration proposed for intangibles so clearly impairs the financial strength of the applicant that continued satisfactory service is dubious. At the other extreme, where a successful operator seeks to expand by acquiring new operating rights for a relatively inconsequential amount, or when an integration contemplates a merely temporary increase in intangible property, Commission consent has been freely given. But between these extremes there is a comparatively uncharted area of Commission discretion, characterized before the Transport case perhaps by a tendency to resolve cloubts in favor of the applicant. A few points upon which a decision may turn have been set forth: the ratio of intangibles to tangibles in relation to the financial position of the applicant, an increase in indebtedness as a means of financing an acquisition, public sale of securities, and across-the-table bargaining. But which way the Commission will go can hardly be predicted with any reliability beyond the general surmise that the larger the applicant and the acquisition, the stricter will be the Commission's attitude.

Concededly the Commission is in a sympathy provoking position. To deny any value on the transfer of intangibles and to guard against increases in indebtedness too severely will thwart desirable combination. To permit uncurbed license in valuation of intangible property would surely produce unifications marked by financial instability and doomed to eventual insolvency. But the Commission has no corner on the sympathy market, for the carrier desiring to unify, especially on a reasonably large scale, can obtain little confident advice from the Commission's decisions. Perhaps the way will be clearer after the Commission has had further opportunity to distill its own ideas. On the other hand, it may be that the whole Commission policy is to keep the field open within broad confines for easier decision of each individual case as it is presented. Yet one wonders if the ultimate consequence of such a policy will not be to contribute further to freezing the motor carrier industry at a stage somewhat near its present level.

Corporate Simplification. The fourth prime factor in the consistency with the public interest doctrine is the requirement of corporate simplification, which seeks to prevent the separation of motor carrier control

107. See cases cited notes 19 and 20 supra. 
from operation. ${ }^{108}$ If the applicant is a holding company which controls or is a concern controlled by operating companies, its proposal to purchase or lease property and operating rights of another carrier invites Commission disapproval, or at least approval conditioned on the real party in interest being substituted as the acquiring company. ${ }^{100}$ Charging that maintenance of such inter-corporate relationships serves no purpose but to confuse shippers, increase expenses and complicate regulation, the Commission has constantly encouraged the creation of simple corporate structures. Consequently whenever a unification proposal, whether by purchase, merger, or consolidation, seeks to take advantage of the economies attendant upon corporate simplification, the Commission is quick to find consistency with the public interest. ${ }^{110}$

Another type of situation provoking Commission disapproval on grounds related to corporate simplification arises where commonly controlled corporate entities operate over duplicate routes. ${ }^{111}$ This was the condition in the Transport case which was sought to be remedied by the supplemental proposal to effect "singleness of title" in the parent company. ${ }^{112}$ The evil of such an arrangement is not alone the needlessly complex corporate structure, but also the attempt to preserve two sets of operating rights over an identical route by singly controlled operation. Such preservation not only prevents economies and improvements in service incident to complete unification, and provides an opportunity for unfair competitive practices between apparent competitors, but also permits later separation and use of such rights when competitive conditions

108. Objectionable separation of control from operation may arise through devices other than corporate affiliates, as, for example, through a lease under which applicant acquires technical control of lessee's property, but lessor agrees to continue operation with its employees. Denver-Chicago Trucking Co.-Control, 15 M. C. C. 257 (1935); Chicago, R. I. \& Pac. Ry.-Lease, 15 M. C. C. 161 (1938).

109. Hudson-Bergen Bus Co.-Lease, 25 M. C. C. 632 (1939); Pacific Frt. Lines Exp.-Purchase, 15 M. C. C. 281 (1938); Dalby Motor Frt. Lines, Ine-Lease, 36 M. C. C. 302 (1940); Hoover Motor Exp. Co., Inc-Purchase, 25 M. C. C. 719 (1939); Míerchants, Inc-Purchase, 15 M. C. C. 225 (1938); Pennsylvania Truck: Lines, Inc-Control, 1 MI. C. C. 101 (1936). If two separate types of operations are conducted, separate entities under common control are permissible. Consolidated Freightways, Inc.Control, 36 MI. C. C. 358 (1941). Or if corporate simplification would prejudice the position of a unified company no corporate simplification will be demanded. American Mlotor Transp., Inc.-Purchase, 35 M. C. C. 41 (1939).

110. Johnson Bus Lines, Inc-Merger, 15 M. C. C. 221 (1938); Cole Motor Serv., Inc-Merger, 15 Mr. C. C. 218 (1938); East Texas Mlotor Frt. Lines-Merger, 15 XI. C. C. 1 (1938); Keeshin Motor Exp. Co., Inc-Leases, 1 A. C. C. 373 (1936); Keeshin Transcon. Frt. Lines, Inc.-Control, 1 Mr. C. C. 317 (1936).

111. Hoover Motor Exp. Co., Inc.-Purchase, 35 M. C. C. 639 (1940); FlormanControl, 35 MI. C. C. 521 (1940); Casaroll-Control, 35 II. C. C. 471 (1940); Younger Bros., Inc-Purchase, 25 MI. C. C. 137 (1939); Interstate Busses Corp. (Conn.)-Purchase, 15 M. C. C. 285 (1938).

112. The Transport Co.-Control, 36 Af. C. C. 61,86 (1940). 
may have been completely altered. For this reason a proposed transaction which would result in two sets of operating rights over duplicate routes coming into the hands of carriers commonly controlled faces certain disapproval unless merger of the operating rights is carried out. ${ }^{113} \mathrm{~A}$ like requirement exists where a single carrier seeks to hold duplicate operating rights. ${ }^{114}$ Similarly, keeping the pattern consistent, applications to lease duplicate rights from another carrier are denied. ${ }^{115}$ In all instances, whatever the unification device, preservation of duplicate rights has been denounced as inconsistent with the public interest.

To complete the picture of the doctrine of consistency with the public interest as drawn by the Commission, ${ }^{116}$ a word must be added about operation of common carriage in competition with contract or private carriage when under single control, an arrangement technically labeled "dual operation." Since it was believed that such dual operation provided particular opportunity for discrimination against shippers, the Motor Carrier Act specifically prohibits it unless the Commission "for good cause shown" shall make a special finding of consistency with

113. See cases cited note 111 supra.

114. A subsequent sale of one set of rights, whether the duplication arose from a difference in the description in the certificate to operate, or from a purchase of such rights, or from the difference between performing "through" and "local" operations as separate service, will not be approved by the Commission. Washington Motor Coach Co., Inc.-Purchase, 35 M. C. C. 627 (1940); Southwestern Transp. Co.-Purchase, 35 M. C. C. 437 (1940) ; H. P. Welch Co.-Purchase, 25 M. C. C. 558 (1939). Merger of duplicate rights is now made a condition to Commission approval of the unification transaction. However, the doctrine condemning route splitting is not extended to a case where vendor possesses confirmed operating rights over alternate routes between the same points. Magee Truck Lines, Inc.-Purchase, 25 M. C. C. 732 (1939).

115. Keeshin Motor Exp. Co., Inc. (I11.)-Lease, 36 M. C. C. 289 (1940); PatzLease, 35 M. C. C. 113 (1940); Consolidated Freightways, Inc.-Lease, 25 M. C. C. 428 (1939); Wilson-Control, 25 M. C. C. 41 (1939); Hawkeye Motor Exp., Inc.-Lease, 15 M. C. C. 456 (1938); Huber-Purchase, 15 M. C. C. 451 (1938).

116. During the early period of regulation, a serious administrative problem was presented to the Commission by the existence of unifications first consummated and then submitted for approval. Because honest misunderstanding of the provisions of $\$ 213$ was a real possibility, and because the only certain enforcement weapon was to dissolve a unification which might otherwise be in the public interest, the Commission was at first very tolerant of previous unlawful operation through unapproved unification. Trans American Frt. Lines, Inc.-Purchase, 5 M. C. C. 712 (1938); Hancock Truck Lines, Inc.-Purchase, 5 M. C. C. 405 (1938); Dohrn Transfer Co.-Purchase, 5 M. C. C. 282 (1937) ; Ziffrin's Overnite Exp., Inc.-Purchase, 5 M. C. C. 246 (1937). However, in Potashnick Truck Serv., Inc--Control, 5 M. C. C. 723 (1938), the Commission published a warning. Since the provisions of the Act were by that time better understood, the time for leniency was said to have expired and futture unifications effected without prior approval were promised prosecution under the general enforcement provisions of the Act which had been expressly extended to $\$ 213$ by the 1938 amendments, or dissolution because prior unlawful operation may in itself make the unification inconsistent with the public interest. Buckingham Transp. Co. of Colo., Inc.-Purchase, 36 M. C. C. 313 (1940). 
the public interest. ${ }^{117}$ The necessity for this special finding is not obviated because duality of operation arises from a unification proceeding instead of from a petition for original authority, and if such a result is a necessary condition to a unification proposal, the application will be denied. ${ }^{118}$ If, however, the dual operation can be eliminated from the proposal without destroying its primary purpose, the Commission will approve the transaction and merely insert a condition against dual operation. ${ }^{119}$

In the main, the applicable doctrine to unification transactions developed under former Section 213 was unaffected by the shift of the statutory provisions to Section $5(2)$. It has already been pointed out that the directions to the Commission contained in new paragraph (c) of Section $5(2)$ to consider the effect of the transaction upon adequate transportation service to the public, and to take into account the total resulting fixed charges, added nothing to existing Commission policy. Paragraph (c), however, did introduce an apparently new factor in its direction to the Commission to consider "the interest of the carrier employees affected." While the Commission had the power prior to this express provision to condition its approval of a unification upon the adoption of a plan affording protection to discharged employees, ${ }^{123}$ that power had never been exercised in any motor carrier proceeding. In fact, in many cases reduced employee expense was regarded by the Commission as an economy in the public interest. ${ }^{121}$ This new require-

117. Motor CARRIER ACT $\$ 210$. If the contract and common carriage are not competitive, both may be conducted by a single carrier. Derr-Purchase, 25 M. C. C. $7 \geqq 9$ (1939).

118. Paxton \& De Lair-Purchase, 25 Mf. C. C. 498 (1939); Scott Bros., Inc-Control, 15 MI. C. C. 419 (1938) ; Universal Service, Inc.-Purchase, 15 AY. C. C. 247 (1933); Oldfields Trucking Co.-Purchase, 5 MI. C. C. 137 (1937). The objectionable features incident to dual operations by a single carrier are not obviated by the conduet of such operations by separate corporations. Ziffrin Truek Lines-Mferger, 25 MI. C. C. 783 (1939).

Certain carriers to be acquired by the Transport Company were engaged in contract as well as common carrier operations. Because of its decision of the case on other grounds the Commission failed to make a study of each operation, as did the Evaminer, but it did affirm the principle prohibiting dual operations and stated summarily that, as no good cause had been shown, control of the contract carriers operating in competition with common carriers was not consistent with public interest. The Transport Co.Control, 36 M. C. C. 61,80 (1940).

119. Campbell Sixty-Six Exp., Inc.-Purchase, 36 AI. C. C. 209 (1940); Penn Ohio New York Exp. Corp.-Purchase, 35 11. C. C. 305 (1940); Hale-Purchase, 15 M. C. C. 126 (1938); Schultz-Purchase, 15 M. C. C. 13 (1938).

120. United States v. Lowden, 308 U. S. 225 (1939).

121. Caplan-Control, 35 Mr. C. C. 477 (1940); Norwalk Truck Line Co--Merger, 35 M. C. C. 459 (1940); Gordon Interstate Inc-Purchase, 15 M. C. C. 30 (1938); Great So. Trucking Co.-Purchase, 5 M1. C. C. 475 (1938); Germann Bros. Motor Transp., Inc-Purchase, 5 M. C. C. 469 (1938) ; Bowen Mfotor Cosches-Consolidation, 5 M. C. C. 344 (1937); Southeastern Greyhound Lines-Securities, 1 M. C. C. 387 (1936). In some cases employee economy was expressly mentioned, in others it was 
ment in paragraph (c) provides an express basis for a shift in approach, but the cases decided since it took effect give little indication that such a shift is forthcoming. Some unification proposals have been approved where it is clear that some contraction in the number of employees was contemplated; ${ }^{122}$ none have been denied for failure to provide for affected employees, nor have there been any compulsory plans for stuch protection imposed by the Commission. The conflicting stresses are clear. Since in many cases the principal economy achieved is the elimination of employees engaged in duplicate functions, the necessity of providing for those employees may well thwart unifications otherwise in the public interest. On the other hand, it seems reasonable that employees who have contributed to the value of an enterprise are entitled to share in the benefits of unified operation. To these opposing factors must be added a third, and one which may contain the clue to Commission action in the immediate future. Since motor carriers, unlike railroads, are expanding transport agencies, and since unified operation promises to facilitate that growth and expansion, employee displacement is, at worst, only a temporary problem. ${ }^{123}$ All of these considerations were presented in the Examiner's proposed report in the Transport case, and while the impairment of employee interest was not found sufficient to warrant denial of the application, a plan for temporary employee protection was devised and made a condition to approval. Unfortunately the Commis. sion's own decision, made on other grounds, prevented treatment of this question and its answer will remain in doubt until the Commission seeks to resolve the question more decisively.

\section{The Railroad Problem in Unifications}

No problem in motor carrier unification is more fascinating or more crucial than fixing the role to be played by the railroads. Today their interest in motor carriage is substantial and constantly growing, and while its extent is not precisely known, the trend is definitely in the direction of co-ordinated service between rail and motor carriers. ${ }^{124}$

implicit in the administrative economies proposed. But in most cases employee savings are small, and it is scarcely surprising that the Commission failed to consider it a pressing problem.

122. Campbell Sixty-Six Exp., Inc.-Purchase, 36 M. C. C. 209 (1940) ; Silver Fleet Motor Exp., Inc.-Merger, 36 M. C. C. 57 (1940) ; Hayes Frt. Lines, Inc.-Purchase, 36 M. C. C. 8 (1940); Heller-Control, 35 M. C. C. 721 (1940).

123. Marshall-Purchase, 36 M. C. C. 33 (1940).

124. In Coordination of Motor Transportation, 182 I. C. C. 263 (1932), Appendix A, 393-400, the Commission presented figures of railroad interest in motor carriers: (1) On June 30, 1930, 18 Class I railroads through direct ownership, subsidiary companies, or stock control, operated 551 trucks and 115 trailers, and 34 Class I railroads operated 3105 busses. In 1927 those railroads operated only 114 trucks, 34 trailers, and 745 busses. (2) On June 30, 1930, Class II railroads operated 8 trucks and 12 busses. 
Co-ordination is theoretically possible in various ways: by means of co-operative formulation of joint rates and through-routes between completely independent railroads and motor carriers, ${ }^{125}$ by unification of the two agencies into large integrated transport companies, or by some compromise between these two extremes. Up to the present the Commission has not prevented integration of rail and motor service because of the possibility of co-operation. ${ }^{126}$ At the same time the policy of the Motor

In 1927 those railroads operated no trucks and 5 busses. (3) Total property investment of the motor carriers in which railroads had an interest was on December 31, 1929, $\$ 46,114,891$.

ICC, Bureau of Statistics (1936), Statement No. 3669, Imes/ments of Sicam Railways in Higlzway Motor Velhicle Enterprises as of May 1, 1936 provides later figures. Class I railroads then had an interest in 128 highway carrier companies. The aggregate capitalization, stocks, bonds, and advances, held by the railroads was $\$ 43,109,361$. On the other hand, those carrier companies in which railroads had an interest had $\$ 59,231,723$ in plant and equipment, a marked increase over the 1929 figure above.

According to a survey made in (May 22, 1937) 102 RAILway Age 879, 78 railro3ds operated motor carriers by bus or truck. The railways operated 5,210 trucks and Railway Express 12,340.

Annual purchases of motor carrier equipment made by the railroads have shown constant increases according to surveys made by Railzcay Age. In 1933, 106 busses, 67 trucks, 2 tractors, 17 trailers, and 37 passenger automobiles were purchased; in 1934, 302 busses, 337 trucks, 27 tractors, 20 trailers, and 45 passenger automobiles were purchased. (Jan. 26, 1935) 98 Rullway Age 168. In 1935 orders were placed for 280 busses, 543 trucks, 106 tractors, 174 trailers and 111 passenger automobiles, and in 1936, for 738 busses, 1276 trucks, 220 tractors, 234 trailers, and 177 passenger automobiles. (Jan. 2, 1937) 102 RaILWAy AgE 91-97. In 1937, 771 busses, 1692 units of freight equipment, and 198 automobiles were ordered; and in 1938, 260 busses, 1647 units of freight equipment, and 164 automobiles were ordered. (Jan. 7, 1939) 106 RAILwAY AGE 93-96. In 1939, 393 busses, 1638 units of freight equipment, and 263 automobiles were purchased; in 1940, 646 busses, 1934 trucks, 311 tractors, 506 trailers, and 302 automobiles were purchased. (Jan. 4, 1941) 110 Ranlway Age 115. These figures are not meant to be a complete survey of railroad purchases, but they do demonstrate the trend of increased activity in the motor carrier field.

According to a private communication from the Bureau of Statistics, a new study of the extent of railroad interest in motor carriers is now being made and will probably be issued sometime this year.

125. Motor carriers favor this solution, and railroads resist it. A resolution adopted by the Association of American Railroads on September 20, 1935, as amended by a resolution adopted June 25, 1937, made it the policy of the Association to discourage member roads "from establishing with motor carriers through routes or joint rates or fares which invade territory not served by such railroad and which is already served by one or more other railroads." This policy was attacked by the Department of Justice as a violation of the Sherman Act, and the resolutions were rescinded by Association resolutions adopted on December 29, 1939, and on or about February 15, 1940. These rescissions were allegedly made under the agreement that the anti-trust action would be dismissed. The Department of Justice, however, insisted that a consent decree be issued. The railroads are contesting this demand on the ground that the question is now moot, and the case remains in the process of litigation.

126. Kansas City So. Transp. Co., Inc., Common Carrier Application, 28 MI. C. C. 5 (1941); Rock Island Motor Transit Co.-Purchase, 5 M. C. C. $451,+56$ (1938). 
Carrier Act definitely arrested as of 1935 any movement toward integrated companies controlled by railroads. Evidencing the fear of railroad domination of the motor carrier field, Section 5(2) (b) compels a carrier applicant "controlled by" or "affiliated" with a railroad to meet more restrictive unification standards than those applied to an ordinary motor carrier applicant. Not only must it be shown that the transaction is consistent with the public interest, but also that the acquiring carrier will be able "to use service by motor vehicle to public advantage in its operations" and that the acquisition will not unduly restrain competition. ${ }^{127}$

The principal objective of this railroad proviso is to prevent the management of motor carriers in the interest of railroads and to promote motor carriage as an independent means of transportation. ${ }^{128}$ Consequently, where the chain of railroad control through stock ownership is direct, there is no question as to the applicability of the restrictions of the railroad proviso, even though control is removed by the intervention of intermediate holding companies. ${ }^{129}$ The phrase "affiliated" with, however, is more bothersome, in spite of its definition in the Act as a relationship because of which "it is reasonable to believe that the affairs of any carrier of which control may be acquired by such person will be managed in the interest of such other carrier." ${ }^{130}$ In interpreting this definition the Commission has directed its attention toward the ownership and managerial relationships between the railroad and the applicant rather than toward the location of the acquired carrier's routes, which might perhaps seem relevant in view of the definition's ambiguity. ${ }^{131}$ Whether the applicant is so closely related to a railroad that

127. See p. 1383 supra.

128. See note 25 supra.

129. Pennsylvania Truck Lines, Inc., Acquisition of Control of Barker Motor Freight, Inc., 1 M. C. C. 101 (1936); Cleveland, Columbus \& Cincinnati H'w'y, Inc.-Purchase, 5 M. C. C. 479 (1938).

130. Interstate Commerce Act \$5(b). The Motor Carrier Act, §213(a)(1), referred, for definition of affiliation, to $\$ 5(8)$ of the Interstate Commerce Act. Although $\S 5(8)$ has been renumbered $\S 5(6)$, the provisions are the same.

131. Suppose an applicant motor carrier is not controlled by a railroad, but is subject to substantial railroad interest. Whether or not the railroad proviso applies depends upon whether or not there is "affiliation" between the two. Now suppose that the applicant proposes to purchase a connecting motor carrier which departs from the railroad route and taps an area unserved by the railroad. Does this fact prevent the possibility of "management in the interest" of the railroad so as to remove the transaction from the bite of the proviso because of lack of affiliation? In a dissent to Northland Greyhound Lines, Inc.-Purchase, 5 M. C. C. 759 (1938), Commissioner Eastman thought it did. But remoteness from the area served by the railroad is a ground used to deny a proposed acquisition of a motor carrier because remoteness prevents the close coordination essential to promoting the public interest. For the same fact to be a cause for excluding the initial applicability of the proviso would defeat its very purpose by permitting car- 
acquired rights and properties will be managed in the interest of the railroad is a question of fact, and, in determining its existence or nonexistence, stock ownership, common officers and directors, and service agreements will be given careful consideration. Some railroad interest in motor carriers is fostered by the Act and by the Commission, ${ }^{132}$ but the point at which such interest becomes affiliation is difficult to mark. Railroad stock interest in a motor carrier of $12 \%, 13 \%, 33 \%$, and even $39 \%{ }^{133}$ has been held not to constitute affiliation. On the other hand, if ownership is approximately equally divided between a railroad and a motor carrier interest, such joint ownership is usually deemed to be affiliation. ${ }^{134}$ To demonstrate the importance of considerations other than stock ownership, there is no better case than Richmond Greyhound Lines, Inc. ${ }^{135}$ where $51 \%$ of applicant motor carrier's stock was owned by the Greyhound Corporation, and $49 \%$ by the Richmond, Frederichsburg and Potomac Railroad. Three of applicant's seven directors, who were also its vice-president, assistant traffic manager, and auditor, were president and director, general traffic manager, and general auditor, respectively, of the railroad. In addition, applicant used the railroad's terminal facilities and its accounting and treasury departments. The proposed acquisition was subjected to the railroad proviso on the ground that the applicant was affiliated with the railroad. This decision was later reversed when the relationship had been altered. ${ }^{130}$ Although the stock ownership remained the same, railroad representatives had resigned from offices in the applicant, and use of railroad terminal facilities, and its accounting and treasury departments had been terminated.

Assuming that railroad control or affiliation does exist, the applicant must show that the proposed transaction will be consistent with public interest and that motor service will be used to public advantage in its rail operations, or as put in a shorthand phrase by the old Act, will

riers in which railroads had a very substantial interest to expand without regard for the location of the acquired routes. The majority realized this, and in the NorthlandGreyhound case attention was carefully restricted to the relationship between the railread and the acquiring carrier.

132. The Act's declaration of a policy of fostering coordination and better relations between motor carriers and other carriers has been understood by the Commission as intended to encourage rail investment in motor carriers. Northland-Greyhound Lines, Inc.-Purchase, 25 AI. C. C. 109, 111 (1939).

133. National Frt. Lines, Inc-Purchase, 15 M. C. C. 687 (1939); Cleveland, Columbus, \& Cincinnati H'w'y, Inc.-Purchase, 36 AI. C. C. 325 (1941); Southwestern Greyhound Lines, Inc-Purchase, 25 MI. C. C. 195 (1939) ; Riss \& Co., Inc-Purchase, 35 1I. C. C. 61 (1939).

134. New England Greyhound Lines, Inc-Purchase, 15 M. C. C. 536 (1938); Northland-Greyhound Lines, Inc.-Purchase, 5 Ar. C. C. 215 (1937).

135. Richmond Greyhound Lines, Inc-Control, 5 M. C. C. 394 (1938). See also E. T. \& W. N. C. Alotor Transp. Co.-Lease, 5 MI. C. C. 196 (1937).

136. Richmond-Greyhound Lines, Inc-Control, 35 MI. C. C. 555 (1940). 
promote the public interest. In any search for the applied content of this vague criterion, the point of departure must necessarily be the Barker case around which the governing doctrine has been unfolded. ${ }^{137}$ The applicant was a motor carrier, controlled by the Pennsylvania Railroad, which proposed to utilize grandfather rights to be acquired in this proceeding in the establishment of co-ordinated rail-motor service for its patrons. Recognizing that in some respects there were inherent public advantages in this new form of transportation endeavor, ${ }^{138}$ and that it presented no undue restraint of competition, the Commission expressed a desire to encourage its widespread adoption. The Commission realized, however, that, in other respects, the proposed acquisition would have resulted in the railroad-controlled applicant entering the motor carrier business as a direct competitor not only of the Pennsylvania Railroad itself and of established motor carriers, but also of other railroads in new areas not theretofore served by the Pennsylvania Railroad. The Commission also recognized that once it permitted acquisition of motor carrier routes by a railroad, it would be powerless to prevent service expansion over such routes, and that the great financial strength and large traffic-soliciting force involved would provide a much more formidable threat to competitors than had been provided by motor carrier predecessors. Faced once again with conflicting desires, the Commission adopted a compromise position and suspended final disposition for sixty days, during which period the applicant was permitted to amend its application and get Commission approval by confining its new operations to service "auxiliary and supplementary" to that performed by the Pennsylvania Railroad in its rail operations and in territory parallel and adjacent to its rail lines. The rationale of its position was clearly set forth:

". . we are not convinced that the way to maintain for the future healthful competition between rail and truck service is to give the railroads full opportunity to go into the kind of truck service which is strictly competitive with, rather than auxiliary to, their rail operations. . . . The financial and soliciting resources of the railroads could easily be so used in this field that the development of independent service would be greatly hampered and restricted, and with ultimate disadvantage to the public." ${ }^{130}$

137. Pennsylvania Truck Lines, Inc., Acquisition of Control of Barker Motor Freight, Inc., 1 M. C. C. 101 (1936).

138. Id. at 111: "The motor vehicle can undoubtedly be used as a very valuable auxiliary or adjunct to railroad service, particularly less-than-carload service, and the many opportunities for such use here have been pointed out of record and are clear. Such coordination of rail and motor-vehicle operations should be encouraged. The result will be a new form of service which should prove of much public advantage."

139. Id. at 111-12. 
A supplemental decision by the Commission in the Barker case, ${ }^{1,4}$ issued after consideration of the amended application, presents even more articulately the permissible scope of railroad operation of motor carriers.

"Approved operations are those which are auxiliary or supplementary to train service. Except as hereafter indicated, nonapproved operations are those which otherwise compete with the railroad itself, those which compete with an established motor carrier, or which invade to a substantial degree territory already adequately served by another rail carrier." 141

In general the Commission indicated that the permissible highway route for auxiliary and supplementary service was the one most closely paralleling the railroad except where use of a non-parallel shortcut highway was clearly in the public interest. Since off-rail points were being otherwise adequately served, Commission approval was conditioned against rendering service to any point which was not a station on the Pennsylvania Railroad. But a proviso was added that if subsequently it were shown that service to some point excluded by this condition had become inadequate, the restriction would be removed.

Back of the decision in the Barker case, of course, is the general assumption that rail and motor carriers each have their own special competence. ${ }^{142}$ Wasteful operation occurs when either agency leaves that field of special competence to engage in operation beyond it. Since this latter practice, which is fairly common today, is a contributing factor to distress in the transportation industry, one solution is the co-ordination of rail service with motor service so as to permit each agency to perform its most efficient function. At least a step in the right direction is made when railroads make provision for supplementation of rail service by motor carriage. In the field of less-than-carload freight, where traffic losses have been especially severe, new horizons are opened by using trucks to facilitate distribution and to substitute for local peddler-freight trains. Passenger service likewise can be made more flexible, more complete, and faster. Economies and service improvements of this type are all sponsored by the Act, ${ }^{143}$ which at the same time seeks to fore-

140. Pennsylvania Truck Lines, Inc-Control, 5 MI. C. C. 9 (1937).

141. Id. at 11-12.

142. Because of relatively high terminal costs for railroads, motor carriers can carry short hauls more economically than can railroads. As distance increases the terminal costs may be more widely spread and the net cost for railroad service becomes less than for motor carriers. Where this distance point, which divides the carriers according to cost of operations, is reached will depend on the type of commodity and the route over which it is hauled. Concuusions on Mrerchannise Trusfic (U. S. Office of the Federal Coordinator 1936); Freight Traffic Report (U. S. Office of the Feleral Cuordinator 1935) ; Coordination of Motor Transportation, 182 I. C. C. 263 (1932).

143. The Motor Carrier Act, $\$ 202$, in its "Declaration of Policy," provided that regulation shall be administered, among other purposes, "to improve the relations br- 
stall their introduction as a means of railroad penetration of motor carriage at the expense of independent operators. ${ }^{144}$

The decision in the Barker case was a compromise between these conflicting policies, and the Commission ever since, with but few minor modifications, has adhered to its principle of encouraging co-ordinated rail-motor service provided that the supplementary motor carriage is closely tied to the railroad tracks. ${ }^{145}$ Regardless of when a rail-controlled motor subsidiary commenced operation, any expansion will be condemned unless it provides for service auxiliary to the railroad. ${ }^{\mathbf{4 0}}$ Many applications have been denied because operating rights to be acquired could not be used in railroad operations, ${ }^{1.47}$ many others have been approved

tween, and coordinate transportation by and regulation of motor carriers and other carriers." The Transportation Act of 1940 repealed $\S 202$, and made a "Declaration of Policy" in more general terms: ". . . all to the end of developing, coordinating, and preserving a national transportation system by water, highway, and rail." INTERSTATE Commeree ACT $\$ 1$.

144. See pp. 1383-85, 1408-1410 supra. Moreover, in the same "Declaration of Policy" of the Motor Carrier Act, 1935, supra note 143, it is made a purpose of regulation "to recognize and preserve the inherent advantages of" motor carriage. The Transportation Act of 1940 adopts the same language and makes it applicable to all carriers. These conflicting statements of policy, and the conflicting provisions for regulation, make it virtually impossible to determine whether the Congressional goal is to maintain independent fully competitive transportation systems or whether it is to provide an artictlated or coordinated system of transportation in which the separate media would tend to lose their identity. Lyon, Abramson \& Associates, 2 Government and Economic Life (1940) 842 .

145. Among the Commissioners, Mr. Eastman is probably the most vigorous proponent of rail-motor coordination. Carrying back to the Commission views crystalized from his work as Federal Coordinator, he stated, in a special concurrence to Union Pac. R. R. -Control, 15 M. C. C. 101, 108 (1938): "I believe very strongly in the use of motortrucks in coordination with rail operations, and that they can be so used to much advantage in providing a less costly, more flexible, and more convenient scrvice." Sce also note 142 stipra.

146. However, a motor carrier subsidiary of a railroad may continue operations in a territory not served by the railroad directly if those operations were begun before the effective date of the Act. But such a carrier may make no new acquisitions under $\$ 5(2)$ which provide service apart from the rail service.

147. On January 1, 1941, nineteen denials had been made by the Commission because an applicant owned by or affiliated with a railroad failed to show that the acquisition would enable it to use motor service to public advantage in rail operations, or that the acquisition would not unduly restrain competition. See note 168 infra. Illustrativc of the various factors involved in denials on the former ground are C. W. Motor Lines, Inc.-Purchase, 35 M. C. C. 103 (1940); Scott Bros., Inc-Control, 15 M. C. C. 419 (1938); Santa Fe Trails of Ill., Inc.-Control, 15 M. C. C. 347 (1938); Northland Greyhound Lines, Inc-Purchase, 5 M. C. C. 759 (1938); Interstate Transit Lines (Nebraska)-Purchase, 5 M. C. C. 369 (1938). See also Mobile \& Ohio Transp. Co. of Ill.-Control, 36 M. C. C. 391 (1941), where the Commission held that the proposed service, since it would only enable the railroad to offer the public the option of traveling by rail or bus, was not auxiliary or supplementary to train service, and hence was not a use of motor service to public advantage in rail operations. 
because the operating rights have been so located as to be auxiliary to the railroad and between-points on the rail line. ${ }^{149}$ Other acquisitions have been approved where the route to be acquired is auxiliary to the rail line but also serves off-rail stations which are not otherwise adequately served, ${ }^{149}$ or where, even though the route to be acquired is not strictly auxiliary to the rail line, it provides a shortcut. ${ }^{120}$ Possible undue restraint of competition is carefully watched, although in the absence of an acquisition of rights which will duplicate those already possessed by the railroad subsidiary, ${ }^{101}$ such undue restraint is not likely to be found. ${ }^{152}$

Modification of the Barker case doctrine has occurred in two respects. In Santa Fe Trail Stages, Inc. ${ }^{163}$ the Commission approved a proposal made by a railroad subsidiary to acquire a route which was neither parallel nor adjacent to the parent railroad. The route, however, served virgin territory. This fact, said the Commission, made the acquisition comparable to the construction of a branch or feeder railroad line into new territory and hence auxiliary and supplementary to its rail operations. With this case as a precedent, the concept of "permissive territory" has since been expanded to include areas which are served by other common carriers, but where the service is inadequate. ${ }^{104}$

The second modification of the Barkcr case doctrine is not so clearcut. In the Barker case it was specifically stated that if the "transportation facilities" of an off-rail point were subsequently shown to be in-

148. Both freight and passenger motor carriage have been so approved. Examples of the former are Gulf Transp. Co.-Purchase, 35 Af. C. C. 699 (1940); Pacific Motor Trucking Co.-Control, 35 MI. C. C. 353 (1940); Texas \& Pac. Motor Transp. Co.Purchase, 5 M. C. C. 653 (1938); Pacific Motor Trucking Co.-Control, 5 M. C. C. 302 (1937); of the latter, Burlington Transp. Co-Purchase, 35 M. C. C. 401 (1940); Gulf Transp. Co.-Purchase, 35 M. C. C. 74 (1940); Gulf Transp. Co.-Purchase, 1 M. C. C. 117 (1936).

149. Frisco Transp. Co.-Purchase, 35 M1. C. C. 132 (1940); Maine Central Transp. Co.-Purchase, 5 MI. C. C. 745 (1938); Norfolk So. Bus Corp.-Purchase, 5 M. C. C. 707 (1938).

150. Frisco Transp. Co.-Purchase, 35 Mr. C. C. 132 (1940); Missouri Pac. Frt. Transp. Co., 15 MI. C. C. 269 (1938); Rio Grande Motor Way, Inc-Purchase, 5 M. C. C. 643 (1938).

151. Union Pac. R. R-Control, 15 M. C. C. 101 (1938); Santa Fe Trail Transp. Co.-Purchase, 5 M. C. C. 115 (1937); Boston \& Afaine Transp. Co.-Purchase, 5 M. C. C. 101 (1937); Union Pac. Stages, Inc.-Purchase, 5 MI. C. C. 63 (1937).

152. Northern Pac. Transp. Co.-Purchase, 15 AI. C. C. 295 (1940); Burlington Transp. Co.-Purchase, 35 Mr. C. C. 401 (1940); Mraine Cent. Transp. Co.-Purchase, 5 M. C. C. 745 (1938); Santa Fe Trail Stages, Inc-Control, 5 M. C. C. 17 (1937).

153. Santa Fe Trail Stages, Inc-Control, 1 M. C. C. 225 (1936).

154. Yreka IV. R. Co.-Purchase, 35 MI. C. C. 337 (1940) ; Black Hills Stages, Inc. -Purchase, 25 MI. C. C. 171 (1939); Northern Pac. Transp. Co.-Purchase, 15 M. C. C. 296 (1938); Santa Fe Trail Transp. Co.-Purchase, 5 M. C. C. 127 (1937); Santa Fe Trails Stages, Inc-Control, 1 M. C. C. 225 (1936); cf. Santa Fe Trails of Ill., IneControl, 15 11. C. C. 347 (1938). 
adequate, the restriction against service by the rail-controlled motor carrier could then be lifted. Likewise, in other cases, it was reasonably held that an off-rail point, within ten miles of the rail line and on a route parallel thereto, which was inadequately served at the time of the original application, could be served as if it were a station on the railroad. ${ }^{155}$ Somewhere in the course of the cases, however, inadequacy of existing service as a condition precedent disappeared and now apparently any point within ten miles of the railroad track and on a parallel route may be served. ${ }^{156}$

The effectiveness of restrictions upon railroad acquisitions of motor carriers would be seriously impaired if at least equal restrictions were not imposed when railroads or their motor carrier subsidiaries apply either for new motor carrier certificates of public convenience and necessity or for extensions to certificates already enjoyed. Consequently, it is not surprising to find that in the certificate cases the Commission has permitted only such motor service as is closely co-ordinated with rail operations. ${ }^{157}$ Indeed, in the leading certificate case, Kansas City Southern Transport Co., ${ }^{158}$ the Commission, in granting an extension of the applicant's certificate, conditioned its approval not only by requiring that motor service be auxiliary to rail service and that it be restricted to

155. Frisco Transp. Co.-Purchase; Maine Cent. Transp. Co.-Purchase; Norfolk So. Bus Corp.-Purchase all cited supra note 149 ; cf. Rock Island Motor Transit Co.Purchase, 5 M. C. C. 629 (1938); Santa Fe Trail Stages, Inc.-Control, 5 M. C. C. 17 (1937).

156. Santa Fe Transp. Co.-Purchase, 5 M. C. C. 1 (1937); Motor Transp. Co.Purchase, 5 MI. C. C. 570 (1938); Rock Island Motor Transit Co.-Purchase, 5 M. C. C. 629 (1938) ; Frisco Transp. Co.-Purchase, 35 M. C. C. 255 (1940); Pacific Motor Trucking Co.-Control, 35 M. C. C. 353 (1940). See also Frisco Transp. Co.-Purchase, 25 M. C. C. 604,608 (1939), where, in approving acquisitions from two individuals, Scofield and Vicory, the Commission said, "In view of the fact that points on Scofield's route not stations on the railroad are served by no other rail or motor carrier, and that points on Vicory's route not stations on the railroad are not more than 8 miles from such a station, a condition imposing service restrictions with respect to either transaction is not warranted."

157. The basis for such restrictions in the certificate cases under $\$ 207(a)$ is not that the rail carrier will be enabled to use motor service to public advantage in its rail operations (the $\S 5(2)$ requirement), but simply the public need for the proposed service. See Santa Fe Trail Stages, Inc. Common Carrier Application, 21 M. C. C. 725, 753 (1940), rehearing denied by full Commission on January 6, 1941; Kansas City So. Transp. Co., Inc. Common Carrier Application, 10 M. C. C. 221, 238 (1938); St. Andrews Bay Transp. Co. Extension of Operations, 3 M. C. C. 711, 715 (1937). Wherc public need has been shown, a railroad has been permitted to depart from its line by means of motor carrier subsidiaries where a new route provided a short-cut or a feeder line to territory not otherwise served. Santa Fe Trail Stages, Inc., supra; St. Andrews Bay Transp. Co., supra. As stated in the text, a similar condition is present in unification cases by way of exception to the Barker case doctrine.

158. Kansas City So. Transp. Co., Inc. Common Carrier Application, 10 M. C. C. 221 (1938). 
stations on the rail line, but also by requiring that shipments transported be limited to those received from or delivered to the railroad under through bills of lading covering prior or subsequent movement by rail. ${ }^{159}$ Though this last condition was often invoked in later cases, ${ }^{\mathbf{1 C 0}}$ its validity has been virtually destroyed by reason of its deletion upon a reopening and amendment of the original Kansas City Southern Transport Co. case on January 24,1941 . $^{161}$ The persuasive reason for this deletion was that the requirement of prior or subsequent movement by rail prevented way-freight trains from being completely replaced by more efficient and more economical motor carriage. The Commission, however, did qualify this deletion by specifically prohibiting the use of motor truck service between certain key points on the ground that the haul was sufficiently long to make rail service more efficient than truck service. ${ }^{102}$ This decision undoubtedly narrows the difference between conditions imposed on coordination in cases involving original certificates or extensions and those involving unifications, ${ }^{103}$ but since the key point limitation is invoked in

159. Naturally, this last condition is applicable only to motor carriage of freight. A contention that a similar condition should be imposed in a unification proposal under $\$ 5$ (2) was expressly denied by the Commission in Pacific Afotor Trucking Co.-Control, 35 M. C. C. $353(1940)$.

160. Indiana R. R. Ext-Fort Wayne via Mfuncie, 27 M. C. C. 176 (1940); Louisiana, A. \& T. Ry. Common Carrier Application, 22 M. C. C. 213 (1940); Indiana R. R. Ext. -Fort Wayne, 21 MT. C. C. 73 (1939); Pacific Motor Trucking Co. Common Carrier Application, 21 M. C. C. 761 (1940); Great No. Ry. Ext., 19 M. C. C. 745 (1939); Chicago, R. I. \& Pac. Ry. Ext.-Iowa, MLo., Kan., and Neb., 19 M. C. C. 702 (1939); Seaboard A. L. Ry. Motor Operation-Gaston-Garnett, S. C., 17 AI. C. C. 413 (1939); Texas \& Pac. Motor Transp. Co. Ext-Big Spring-Pecos, Tex., 14 1f. C. C. 649 (1939); Illinois Cent. R. R. Common Carrier Application, 12 M. C. C. 485 (1939); Texas \& Pac. Motor Transp. Co. Common Carrier Application-Louisians, 10 M. C. C. 525 (1938).

161. Kansas City So. Transp. Co., Inc. Common Carrier Application, 28 M. C. C. 5 (1941). The decision created loud lamentation in the truck industry which proclaimed that the railroads had been given complete authority to take over the trucling companies. Editorial, Order to Inzade, and leading story with banner headlines, $I$. C. C. Opens Trucking Field to Rails, Transport Topics, Feb. 24, 1941, Vol. 15, No. 22, p. 1. Compare Editorial (Afarch 22, 1941) 110 RAILwAY AGE 532, expressing satisfaction that the railroads had successfully resisted motor truck pressure to compel railroads to use independent trucking concerns in coordinated operation.

It appears, however, that the requirement of prior or subsequent movement by rail will still be utilized under certain circumstances. Recently, the Commission granted temporary authority to the Railway Express Agency (railroad owned) to operate over 63 routes in 22 states, thereby enabling railroads to handle less-than-carload freight more efficiently. The authority was conditioned on the service being "auxiliary to and supplementary of" railway express service and on the traffic having an "immediately prior or immediately subsequent rail movement by the agency." Transport Topies, May 26, 1941, Vol. 15, No. 35, p. 1.

162. Kansas City So. Transp. Co., Inc. Common Carrier Application, 28 Mr. C. C. 5, 11 (1941).

163. The Kansas City Southern case also narrowed the difference between considerations for certification and unification with respect to effect on competition, the Com- 
the former class of cases, in addition to the Barker case limitations, the policy against widespread rail invasion of the motor carrier filed expressed in Section 5(2) seems adequately protected from circumvention. ${ }^{\mathbf{1 0 4}}$

\section{A Survey of Commission Activity}

During 1936, the first full year of Commission supervision over motor carriage, 122 applications for authority to unify under Section 213 were filed with the Commission. Since that time, however, the number of applications filed annually with the Commission has been considerably larger: 286 in 1937, 214 in 1938, 305 in 1939, and 314 in 1940.100 The total number of applications filed as of November 1, 1940, when the last Annual Report of the Commission was issued, was 1,241, and at least 1,014 of these applications had received disposition. ${ }^{106}$

Of this total number of dispositions, 46 were dismissed by the Commission for lack of jurisdiction, and only 48 , or less than $5 \%$, were denied on their merits. ${ }^{167}$ Twenty-nine of the applications denied involved

mission stating: "It was further found, and properly we think, that the development of the coordinated service would not seriously endanger the operations of existing motor carriers, but that, in any event, the public ought not to be deprived of the benefit of an improved service merely because it might divert some traffic from other carriers, pointing out that had that principle been followed no motor carrier service could have been developed." (Italics supplied). Commissioner Lee dissented on this question, charging that Commission disregard for the necessity for added service and its effect on competition made it easier for railroads than for independent truckers to meet the requirements of public convenience and necessity.

164. The relevance of such considerations to passenger transportation by bus is a problem not to be explored here. Certainly rail-controlled bus companies have been able to add new routes to those owned in 1935 when the Motor Carrier Act becaun effective, and they have maintained through bus schedules between key points so that rail travel for part of a journey, while possible, is not necessarily involved. A good example is the through service offered by Santa $\mathrm{Fe}$ Trailways, controlled by the Atchison, Topeka \& Santa Fe Railway, from Chicago to Los Angeles and San Francisco, the history of which is outlined in Santa Fe Trail Stages, Inc. Common Carrier Application, 21 M. C. C. 725 (1940). Such a system, however, by reason of its coordinated rail and bus schedules all along its routes and its connecting and feeder lines, does provide a coordinated rail and bus service as well as independent bus carriage of the type in the foregoing example. On the other hand it is clear that an acquisition will not be approved which has no consequence other than to enable a rail carrier to offer the public the option of traveling by either rail or bus. Mobile \& Ohio Transp. Co. of Ill.Control, 36 M. C. C. 391 (1941).

165. 50th ANw. Rep. I. C. C. (1936) 80; 51st ANn. Rep. I. C. C. (1937) 77; 52d Ann. Rep. I. C. C. (1938) 98; 53d Ann. Rep. I. C. C. (1939) 112; 54th Ann. Rep. I. C. C. $(1940) 111$.

166. Ibid.

167. The denials and dismissals are counted only up to November 1,1940 , so as to make them comparable to the latest official figure available for total applications filed and dispositions made. In appraising these figures it must be remembered that many cases have arisen in which the application has been approved, but the approval has re- 
unification of one independent motor carrier with another, and the remaining 19 involved an applicant railroad or a motor carrier owned by or affiliated with a railroad. ${ }^{108}$ The astonishingly small number of denials makes it clear that obstacles to unification imposed by the Act, and its administration by the Commission, are by no means insuperable. The contrary is true, since authority for one independent motor carrier to unify with another will be granted almost as a matter of course if the consideration involved is reasonable, if no preservation of duplicate rights is contemplated, and if dual operation is not involved. On the other hand, when a railroad or a motor carrier owned by or affiliated with a railroad seeks to acquire further properties, the cases show the effect of the added restrictions imposed by the Act, in that the 19 denials of such acquisitions constitute a larger proportion of the applications filed than do the 29 denials of proposals made by independent motor carriers.

Even though doctrinal requirements incident to a combination of two independent motor carriers are easily met, the necessity for Commission approval in itself is probably a damper upon unification transactions, and since the Resler case it is clear that no unification transaction is entircly

quired consideration to be scaled down or has been conditioned against the preservation of duplicate routes or dual operation.

168. Codrmission Denials of Applicatjons for Unification Aarong Independent Mlotor Carriers.

Grosinds for

Number of Denial.

Denials.

Preservation of duplicate rights by a single operation, or by operation conducted by commonly controlled

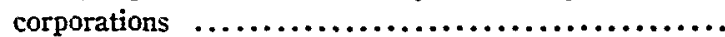

Excessive consideration .............................

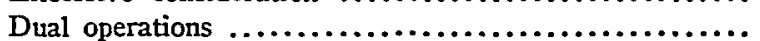

Undue restraint upon competition $\ldots . . . \ldots \ldots \ldots \ldots . .$.

Division of responsibility to the public $\ldots \ldots \ldots \ldots \ldots \ldots$

Failure to show consistency with the public interest....

Joint control over the acquisition

..................

* Two were later reversed.

Commission Denials of Applications for Unificatron Betwee: a Motor Carrier axd a Railroad or a Mfotor Carrier OwNed by or Affiliated witr a Rallroad.

Groninds for

Denial.

Route to be acquired failed to comply with the Barker case requirements that it be auxiliary, parallel, and limited to stations on the rail line...............

Undue restraint of competition $\ldots \ldots \ldots \ldots \ldots \ldots \ldots \ldots .$.

Division of responsibility to the public $\ldots \ldots \ldots \ldots \ldots \ldots$.

Joint control over the acquisition
Number of

Denials. 
free from Commission supervision. The procedure incident to approval is expensive and slow. The expense of filing applications, appearing at hearings, and employing counsel can hardly be viewed with equanimity by a small operator who wants to buy out John Jones for $\$ 300$, but the necessary delay is of more vital importance to large and small operators alike. A survey of reported cases shows that the time which elapsed between formal submission of an application and its disposition averaged 7 months in 1936, 10 months in 1937, almost 13 months in 1938,8 months in 1939 , and 7 months in $1940 . .^{160}$ An average time of 7 months does not seem alarmingly long for the working of administrative process, but it is certainly long enough for the occurrence of important changes in conditions. Equipment under contract of sale, thereby released from the restraint of ownership, can be irremediably injured in 7 months; patrons may be so neglected as to impair goodwill; a new competitor may be given authority to operate, and rates may be forced down or wages up. Of these possible adversities only injury to equipment may be avoided by contract stipulation. There can be little doubt that delay has caused many an operator, and many a banker, to turn away from otherwise attractive unification opportunities. On the other hand, orderly administration of the Act seems to demand supervision over all unifications, and some delay is a necessary incident. Such delay, however, should be reduced as much as possible, and this the Commission seems endeavoring to do.

Questions not only of interest but of important implication, which apparently have never been thoroughly investigated, are those relating to the scope of the unifications which are now being made. Are most acquiring carriers large, or are they small? Are the carriers acquired small, or are large systems being linked together full-grown? Does the trend in truck unification differ in these respects from that in bus unification ? ${ }^{170}$ In the hope that answers to these questions might be found

169. In making this survey, only unification cases were used, and applications were classified according to the nearest month. Omissions occurred because some cases failed to state the date of original application, and others, involving supplementary reports, failed to make clear when the petition for amendment or reconsideration was filed. Where there were more than one application, or where there were amended applications, the date of the earliest application was adopted.

It will be noted that the average time increases with the volume of work until 1938. After that year, however, the average time decreases in spite of an increase in the volume of work handled. This expedition is probably due more to increased facility by the Bureau of Motor Carriers than to procedural simplifications introduced by the amendments of 1938, for even though hearings are no longer required they continue to be held in "nearly every' case." AtT'y Gen's Comm. on Admin. Proc.: Administrative ProCedure in Governarenr Agencies, Pt. 11, (Interstate Commerce Commission) 79.81.

170. It was also thought that a picture of unification activity might disclose marked geographical variations, but geographic classification proved extremely difficult because rigid boundaries cannot satisfactorily be drawn and because routes acquired are often 
from the cases, those decided in 1940 were examined and appraised. Unfortunately, the data appearing in the reports was too scanty for entirely satisfactory analysis and comparison. Only seldom was the number of carriers owned by either party, or involved in the transaction stated. Balance sheets were outlined, but generally with insufficient particularity to warrant write-downs. Consequently, for purchase cases the stated gross assets of the acquiring carrier were used as the criterion of its size, and the consideration agreed upon was used as the criterion for the size of the acquisition. This pattern breaks down partially in lease cases, where the total lease consideration was employed to estimate the size of the acquisition, and breaks down entirely in merger cases where no monetary consideration is transferred. In merger cases the stated gross value of the assets of all parties to the unification were used to determine their respective size. ${ }^{171}$ Truck unifications classified in this survey number 147 , of which 111 acquisitions were made by carriers with assets of more than $\$ 50,000$ and less than $\$ 500,000$. ${ }^{172}$ Twelve carriers with assets

rambling in character. Consequently, 29 of 169 transactions were classificd as interregional. Of the remainder, the Northwest had fewest with $\delta$ and the Pacific Coast next with 12. This low figure for the Pacific Coast is probably because many transactions involving west coast concerns were unifications with carriers operating east of the Rockies, and consequently classed as inter-regional. The Northeast had $\mathbf{2 b}$, the Southeast had 28 , the Southwest had 26, and the Mid-West had 41. The predominance of unification in the Mid-West is at least partly due to the inclusion in that area of a large number of important states: Illinois, Mfissouri, Kansas, Iowa, Minnesota, Wisconsin, Michigan, Ohio, and Indiana.

171. There were 9 consolidations with the pro-forma balance sheet of the new corporations showing, in round figures, the following gross assets: (1) $\$ 270,00012$ trucking companies); (2) $\$ 65,000$ (2 trucking companies); (3) \$136,000 (2 trucking companies); (4) $\$ 200,000$ ( 3 trucking companies); (5) $\$ 146,000$ (3 bus companies); (6) $\$ 577,000$ ( 3 trucking companies); ( 7 ) $\$ 60,000$ (3 trucking companies); ( 8 ) $\$ 450,000$ (2 bus companies); (9) $\$ 124,000$ (trucking companies).

172. It should be noted that the chart presented here does not include those transactions excluded from the unification provisions because fewer than 20 vehicles were involved, or because only intrastate rights were acquired, or, because, for any other reason, Commission jurisdiction was absent.

Trucks

\begin{tabular}{|c|c|c|c|c|c|c|c|c|c|}
\hline $\begin{array}{c}\text { Size of } \\
\text { Acquiring } \\
\text { Carrier }\end{array}$ & $\begin{array}{c}0 \\
\text { to } \\
\$ 10,000\end{array}$ & $\mid \begin{array}{c}\$ 10,000 \\
\text { to } \\
25,000\end{array}$ & $\begin{array}{c}25,000 \\
\text { to } \\
50,000\end{array}$ & $\begin{array}{c}50,000 \\
\text { to } \\
100,000\end{array}$ & $\begin{array}{l}100,000 \\
\text { to } \\
200,000\end{array}$ & $\begin{array}{c}200,000 \\
\text { to } \\
500,000\end{array}$ & $\left|\begin{array}{c}300,000 \\
t 0 \\
1,000,000\end{array}\right|$ & $\left|\begin{array}{c}1,000,0001 \\
\text { and } \\
\text { over }\end{array}\right|$ & Totals \\
\hline $\begin{array}{l}0-\$ 10000 \\
10000 \text { to } 25000 \\
25000 \text { to } 50000 \\
50000 \text { to } 100,000 \\
100,000 \text { to } 200,000 \\
200,000 \text { to } 500,000 \\
500,000 \text { to } 1,000,000 \\
1,000,000 \text { and over }\end{array}$ & $\begin{array}{r}1 \\
16 \\
21 \\
28 \\
19 \\
5 \\
3\end{array}$ & $\begin{array}{r}1 \\
1 \\
7 \\
7 \\
12 \\
4 \\
1\end{array}$ & $\begin{array}{l}1 \\
4 \\
2 \\
1\end{array}$ & 2 & 1 & $\begin{array}{l}1 \\
1\end{array}$ & & 1 & $\begin{array}{r}1 \\
1 \\
18 \\
31 \\
4 \\
35 \\
12 \\
4\end{array}$ \\
\hline Totals & 96 & 34 & 8 & 6 & 1 & 2 & & & 147 \\
\hline
\end{tabular}


of more than $\$ 500,000$ and less than $\$ 1,000,000$, and four carriers with more than $\$ 1,000,000$ in assets acquired new properties, while, at the other extreme, only two carriers with assets of less than $\$ 25,000$ made acquisitions. Of the total of 147 transactions, 96 involved consideration of an expenditure of less than $\$ 10,000,34$ involved between $\$ 10,000$ and $\$ 25,000$, and only 17 more than $\$ 25,000$.

Only 22 bus acquisitions were found for classification, ${ }^{173}$ and ten of the 22 transactions concerned an acquiring carrier with assets of more than $\$ 1,000,000$. However, all of the ten acquisitions were purchased for less than $\$ 50,000$, and seven for less than $\$ 10,000$. Of the 22 transactions, 17 acquiring carriers had assets of more than $\$ 200,000$, and only two had assets of less than $\$ 100,000$. The size of the acquisition shows more correspondence to truck unifications, for 18 acquisitions were made for less than $\$ 25,000$, and 13 for less than $\$ 10,000$.

This survey is not presented as a completely accurate appraisal of the magnitude of unification transactions, but it does seem to be indicative of certain broad trends. Truck unifications are numerous and are being made predominantly by middle-sized concerns, with only slight activity among the very large and the very small companies. The number of bus unifications is smaller, but the acquiring bus companies tend to be larger than the acquiring truck companies. Both of these results were to be expected, since the bus industry is far more integrated and mature than the truck industry. ${ }^{174}$ On the other hand, in contrast to these differences between bus and truck unification, there is also a striking parallel in that the carriers acquired by both are small in size. The growth into systems, if there is such a growth, has been proceeding very slowly, and accelerated systematization by large scale acquisitions will probably remain, since the Transport case, only a possibility of the future.

\begin{tabular}{|c|c|c|c|c|c|c|c|c|c|}
\hline \multicolumn{10}{|c|}{ Busses } \\
\hline $\begin{array}{l}\text { Size of } \\
\text { Acquiring } \\
\text { Carrier }\end{array}$ & $\begin{array}{c}0 \\
\text { to } \\
\$ 10,000\end{array}$ & $\begin{array}{l}\$ 10,000 \\
\text { to } \\
25,000\end{array}$ & $\begin{array}{c}25,000 \\
\text { to } \\
50,000\end{array}$ & $\begin{array}{c}50,000 \\
\text { to } \\
100,000\end{array}$ & $\begin{array}{c}100,000 \\
\text { to } \\
200,000\end{array}$ & $\begin{array}{c}200,000 \\
\text { to } \\
500,000\end{array}$ & $\begin{array}{c}500,000 \\
\text { to } \\
1,000,000\end{array}$ & $\left|\begin{array}{c}1,000,000 \\
\text { and } \\
\text { over }\end{array}\right|$ & Totals \\
\hline $\begin{array}{l}0 \text { to } \$ 10000 \\
10000 \text { to } 25000 \\
25000 \text { to } 50000 \\
50000 \text { to } 100,000 \\
100,000 \text { to } 200,000 \\
200,000 \text { to } 500,000 \\
500,000 \text { to } 1,000,000 \\
1,000,000 \text { and over }\end{array}$ & $\begin{array}{l}2 \\
1 \\
2 \\
7\end{array}$ & $\begin{array}{l}1 \\
1 \\
2 \\
1\end{array}$ & 2 & 1 & & 1 & & & $\begin{array}{r}1 \\
1 \\
3 \\
5 \\
2 \\
10\end{array}$ \\
\hline Totals & 13 & 5 & 2 & 1 & & 1 & & & 22 \\
\hline
\end{tabular}

173. See chart in note 172 supra.

174. Compare the present situation with that in 1932, as set forth in Coordination of Motor Transportation, 182 I. C. C. 263, 276 (1932), where the Commission said: "High-" way trucking is organized on the basis of a large proportion of small and meditum-sized operators and a small number of large ones. There are none of a size or territorial extent comparable with that of the largest bus operators, as discussed below. The tendency toward consolidation is far less noticeable in the case of truck than of bus lines." 
The extent to which this relatively slow growth into systems and virtual absence of large-scale unification is attributable to federal regulation under the Motor Carrier Act of 1935 cannot be defined with certainty. Casual factors in Commission policy may he a combinatiun uf the view that small scale operation is most efficient with the view that motor carrier companies independent of other transportatiun asencies are essential for industrial good-health. But it may he that the (immission has deliberately avoided open espousal of any hruad pulicy pusition and is temporarily content to apply a brake on tun rapid comluination of motor carriers into large concerns. This is particularly evident in terms of the doctrine developed as a rationale for its policy in the lenial and qualified approval cases. Despite the fact that appruval has heen freely granted to the bulk of unification transactions, it is entirely pussible that the consequence of the present Commission point of view. if maintained without change, will be to freeze motor carriage development at some point not far above its present level. 